\title{
Promiscuous arbuscular mycorrhizal symbiosis of yam (Dioscorea spp.), a key staple crop in West Africa
}

\author{
Atti Tchabi • Stefanie Burger • Danny Coyne • \\ Fabien Hountondji • Louis Lawouin • \\ Andres Wiemken • Fritz Oehl
}

Received: 22 December 2008 / Accepted: 19 March 2009/Published online: 3 April 2009

(C) Springer-Verlag 2009

\begin{abstract}
Yam (Dioscorea spp.) is a tuberous staple food crop of major importance in the sub-Saharan savannas of West Africa. Optimal yields commonly are obtained only in the first year following slash-and-burn in the shifting cultivation systems. It appears that the yield decline in subsequent years is not merely caused by soil nutrient depletion but might be due to a loss of the beneficial soil microflora, including arbuscular mycorrhizal fungi (AMF), associated with tropical "tree-aspect" savannas and dry forests that are the natural habitats of the wild relatives of yam. Our objective was to study the AMF communities of natural savannas and adjacent yam fields in the Southern Guinea savanna of Benin. AMF were identified by mor-
\end{abstract}

\footnotetext{
A. Tchabi $\cdot$ S. Burger $\cdot$ A. Wiemken $\cdot$ F. Oehl

Plant Science Center Zurich-Basel, Institute of Botany,

University of Basel,

Hebelstrasse 1,

CH-4056 Basel, Switzerland

A. Tchabi $\cdot$ F. Hountondji $\cdot$ L. Lawouin

International Institute of Tropical Agriculture (IITA),

08 BP 0932 Cotonou, Benin

D. Coyne

International Institute of Tropical Agriculture (IITA),

Oyo Road,

Ibadan, Nigeria

D. Coyne

Lambourn Ltd,

Carolyn House, 26 Dingwall Road,

Croydon CR9 3EE, UK

F. Oehl $(\bowtie)$

Ecological Farming Systems,

Agroscope Reckenholz-Tänikon Research Station (ART),

Reckenholzstrasse 191,

CH-8046 Zürich, Switzerland

e-mail: Fritz.Oehl@art.admin.ch
}

photyping spores in the soil from the field sites and in AMF trap cultures with Sorghum bicolor and yam (Dioscorea rotundata and Dioscorea cayenensis) as bait plants. AMF species richness was higher in the savanna than in the yamfield soils (18-25 vs. 11-16 spp.), but similar for both ecosystems (29-36 spp.) according to the observations in trap cultures. Inoculation of trap cultures with soil sampled during the dry season led to high AMF root colonization, spore production, and species richness (overall $45 \mathrm{spp}$.) whereas inoculation with wet-season soil was inefficient (two spp. only). The use of $D$. cayenensis and D. rotundata as baits yielded 28 and 29 AMF species, respectively, and S. bicolor 37 species. AMF root colonization, however, was higher in yam than in sorghum (70-95 vs. 11-20\%). After 8 months of trap culturing, the mycorrhizal yam had a higher tuber biomass than the nonmycorrhizal controls. The AMF actually colonizing D. rotundata roots in the field were also studied using a novel field sampling procedure for molecular analyses. Multiple phylotaxa were detected that corresponded with the spore morphotypes observed. It is, therefore, likely that the legacy of indigenous AMF from the natural savanna plays a crucial role for yam productivity, particularly in the low-input traditional farming systems prevailing in West Africa.

Keywords Beneficial soil biota - Biodiversity .

DNA extraction · Sustainable agriculture · Tropics .

Tuber crop

\section{Introduction}

Yam (Dioscorea spp.) is a tuber crop widely cultivated in the humid and subhumid lowland regions of sub-Saharan West Africa, the Caribbean, and Atlantic coastal lines of 
tropical America and Asia (Onwueme and Haverkort 1991; Sotomayor-Ramirez et al. 2003; Suja et al. 2003; Baimey et al. 2006; Egesi et al. 2007a). In West Africa, yam is the most important tuber crop in terms of area coverage and a key staple food, particularly in Nigeria, Benin, and Togo (Kalu and Erhabor 1990; Olasantan 1999; Ile et al. 2006; Baimey et al. 2006). More than $90 \%$ of the global production (40 million tons fresh tubers per year) is produced in West Africa (Ravi et al. 1996; FAOSTAT 2007). Additionally, yam plays an important cultural role in the traditions of West Africa (Coursey 1984; Orkwor 1998). Regionally, yam production is relatively static despite the area under production steadily increasing (IITA 2006), indicating a gradual decrease in productivity. Major constraints for yam production were presumed to be low soil fertility, e.g., due to macro-and micronutrient deficiency (O'Sullivan and Ernest 2007) or damage by plant parasitic nematodes and virus diseases (Odu et al. 2004; Baimey et al. 2005; Egesi et al. 2007b). In terms of nutrient use, yam is a demanding crop, and consequently, it is planted traditionally at the beginning of the crop rotation cycle following slash-and-burn of forest respective savannas with significant tree components or long-term fallow vegetation (Carsky et al. 2001; O'Sullivan and Jenner 2006). However, such suitable land becomes scarce due to increasing land-use intensity driven by demographic pressure and dwindling land availability. Furthermore, inappropriately cultivated lands are exposed to erosion and soil degradation (Maduakor et al. 1984; Carsky et al. 2001; Salako et al. 2007). Inconsistent results were obtained in studies on the efficiency and economics of inorganic fertilizer application to yam. For example, Ferguson (1973) found that Dioscorea alata did not respond to phosphorus (P) fertilizer, particularly when seed yam sets of $100 \mathrm{~g}$ or more were used. He proposed that the accumulated $\mathrm{P}$ in the sets were sufficient for newly sprouting vines during early growth or, alternatively, that yam depends on arbuscular mycorrhizal fungi (AMF) for $\mathrm{P}$ acquisition. Similarly, trials in the Southern Guinea savanna of Benin showed that yam yields did not increase following application of ammonium super phosphate (Baimey 2005). Sotomayor-Ramirez et al. (2003) found that the application of micronutrients was most important for increasing yam (D. alata and D. rotundata) production, while a moderate application was adequate for macronutrients. Ahn (1993) attributed the moderate or limited need of $\mathrm{P}$ by yam to possible mycorrhizal benefits, as did Vander Zaag and Fox (1980), when observing that $D$. esculenta and D. rotundata did not respond to P fertilization in field experiments in Hawaii and Ghana but had decreasing levels of AM root colonization with increasing $\mathrm{P}$ fertilization. Valenzuela and deFrank (1995), in a review, also speculated that yam may depend on a mycorrhizal association to meet its $\mathrm{P}$ requirements.
Knowledge on the mycorrhizal status of yam has remained scarce so far with only limited information available (Ahulu et al. 2005; Oyetunji and Afolayan 2007), especially on $D$. cayenensis and D. rotundata that are preferably cuvltiated in sub-Saharan Africa. Micropropagated D. rotundata cvs. TDr131 and TDr179, however, were successfully inoculated with a mixture of AMF species when transferring from humidity chambers to field conditions (Uchendu 2000). Nevertheless, the extent to which yam is dependent on, or associated with AMF, has remained relatively unknown (Dare et al. 2007).

Recently, we studied the AMF diversity in soils from three ecological zones within the "yam belt" of West Africa (Tchabi et al. 2008) and found a high diversity for "natural" sites, with a relatively rapid decline in species richness observed with subsequent crops following yam in the crop rotation. In the present study, we focused further on the association of AMF with yam using data from sites in the Southern Guinea savanna (SGS) of Benin. Based on spore morphotyping, we determined the AMF species composition in three natural savanna sites and adjacent, recently cleared areas, under yam cultivation. Moreover, we set up trap cultures with soil inocula from individual sites using the host plants Stylosanthes guianensis and Brachiaria humidicola in a first trap culture system with wet season soil as AMF inoculum. In a second experiment, we used preferably dry season soil as AMF inoculum and each one cultivar of $D$. cayenensis and D. rotundata as bait plants to specifically identify the AMF symbionts associated with yam. In this trap culture experiment, trap cultures were also established with a commonly used bait plant, Sorghum bicolor. In all trap cultures, AMF root colonization, spore density, and species richness were determined as well as yam shoot and tuber weights. Furthermore, the AMF community colonizing $D$. rotundata roots in the field was assessed by molecular tools using a novel technique for DNA extraction and preservation.

\section{Materials and methods}

Study area and field sites

The SGS of Benin is situated between $7^{\circ}$ and $9^{\circ} \mathrm{N}$ latitude in the sub-humid tropical savanna about $400 \mathrm{~m}$ asl. The soils are termed "ferruginous" and generally classified as Ferralsols according to FAO (2007). The area is characterized by a wet season between April and October and a dry season between November and March, with a variant towards the southern latitude, where a short dry spell occurs during the wet season around August. The mean annual rainfall is $1,000-1,200 \mathrm{~mm}$, and the natural vegetation is composed mainly of Combretaceae, Mimosaceae, 
Fabaceae, and grass layers of Poaceae (mainly Andropogon gayanus; Adjakidje 1984; Adjanohoun 1989).

Six sites were selected: three natural savannas (ns1-ns3), undisturbed for 25-30 years, and three fields cultivated with yam immediately following clearance of the natural vegetation (yf1-yf3). One important criterium for site selection dictated that the yam fields needed to be situated in close proximity to the adjacent savanna sites (Table 1).

Soil sampling and analyses

Soils were sampled twice at each site: first towards the end of the wet season (September-October 2004), when yam plants were aged approximately 5-6 months and close to harvest (harvest period occurs between September and January in the study area; Ile et al. 2007). The second sampling occurred during the dry season (February 2005) shortly after yam harvest when the vegetation was barren. For each sampling occasion and site, four replicate quadrant plots $\left(100 \mathrm{~m}^{2}\right)$ were determined, with six soil cores per quadrant randomly removed using a $6-\mathrm{cm}$ diameter corer, to a depth of $20 \mathrm{~cm}$. The six soil core samples were combined into a composite sample (replicate) per site for each occasion. Samples were air-dried on an open bench in the greenhouse for $72 \mathrm{~h}$ at the International Institute of Tropical Agriculture (IITA) station in Abomey-Calavi, Benin, then maintained in the refrigerator at $4^{\circ} \mathrm{C}$ for 2 weeks and transferred to the Institute of Botany in Basel, Switzerland.

Each air-dried soil sample was divided into three equal subsets which were used to: (a) determine selected soil chemical parameters $(\mathrm{pH}$, organic carbon, and available $\mathrm{P}$; Table 1), (b) establish AMF trap cultures, and (c) isolate and identify AMF spores. The two methods used for describing available $P$ represent two standard methods ("P-Morgan" (Na-acetate), and "P-Citrate") that are often used to measure easily respective slowly available $\mathrm{P}$ in slightly acidic soils (Oehl et al. 2005; Tchabi et al. 2008). For three sites (ns1, ns2, and yf3), the spore data from the wet season field samples have been reported previously (Tchabi et al. 2008).

Source and acclimatization of yam plantlets

Tissue culture plantlets of $D$. rotundata and $D$. cayenensis were obtained from IITA-Ibadan, Nigeria. Plantlets were multiplied under in vitro conditions by subculturing nodal segments from established in vitro plantlets in culture-tubes containing specific yam propagation media ( $\mathrm{Ng} 1988$, 1992, 1994). Plantlets were regenerated in a culture room with a $12 \mathrm{~h}$ photoperiod, 3,000 lx light intensity, at $27 \pm 1^{\circ} \mathrm{C}$ and $70 \pm 5 \%$ relative humidity.

The in vitro plantlets were conveyed to Basel, Switzerland, where they were planted out in $50 \mathrm{~cm}^{3}$ pots containing a 2:1:1 $w / w / w$ substrate mixture of sterilized peat, Vermiculite (GERMEX, Vermica AG, Switzerland), and quartz sand (Quartz d'Alsace, 5\% of free silica; Smurfit Company, France). The substrate $\mathrm{pH}\left(\mathrm{H}_{2} \mathrm{O}\right)$ was 5.0 and the substrate contained $4.5 \%$ organic matter, 220 and $703 \mathrm{mg} \mathrm{g}^{-1}$ easily and slowly available $\mathrm{P}$ (P-acetate and P-citrate, respectively), and $717 \mathrm{mg} \mathrm{g}^{-1}$ easily available potassium (K-acetate). The plantlets were acclimatized for 3 weeks in trays covered initially with a plastic sheet to retain a high relative humidity $(70 \%)$. Plantlets were maintained in the greenhouse with a day/night regime of $12 / 12 \mathrm{~h}$ and $25 / 21^{\circ} \mathrm{C}$ and irrigated once or twice per day. After 3 days, the plastic sheet was progressively removed for increasingly longer periods (6-12 h) per day over the following week, before the cover sheet was removed completely at three weeks. One week later, the plantlets were transferred into the trap culture pots inoculated with AMF.

Table 1 Geographic position of study sites and selected chemical soil parameters: natural savannas (ns1-3) undisturbed for at least 25-30 years and adjacent yam fields (yfl-3) sampled during the first year following forest clearance

\begin{tabular}{|c|c|c|c|c|c|c|c|c|c|}
\hline \multirow[t]{2}{*}{ Sampling sites } & \multirow[t]{2}{*}{ Geographic position } & \multicolumn{2}{|c|}{$\mathrm{pH}\left(\mathrm{H}_{2} 0\right)$} & \multicolumn{2}{|c|}{$\begin{array}{l}\text { Organic } \\
\mathrm{C} \mathrm{g} \mathrm{kg}^{-1}\end{array}$} & \multicolumn{2}{|c|}{$\begin{array}{l}\text { Available P } \\
\text { (Na-acetate) } \mathrm{mg} \mathrm{kg}^{-1}\end{array}$} & \multicolumn{2}{|c|}{$\begin{array}{l}\text { Available P } \\
\text { (citrate) } \mathrm{mg} \mathrm{kg}^{-1}\end{array}$} \\
\hline & & w.s. & d.s. & w.s. & d.s. & w.s. & d.s. & d.s. & w.s. \\
\hline Natural Savanna 1 (ns1) & $07^{\circ} 45.739^{\prime} \mathrm{N} ; 002^{\circ} 27.519^{\prime} \mathrm{E}$ & 6.7 & 6.8 & 24.9 & 26.1 & 52.8 & 74.2 & 83.0 & 144.1 \\
\hline Natural Savanna 2 (ns2) & $07^{\circ} 57.217^{\prime} \mathrm{N} ; 002^{\circ} 26.935^{\prime} \mathrm{E}$ & 7.2 & 7.2 & 44.1 & 37.7 & 27.3 & 27.0 & 37.6 & 35.8 \\
\hline Natural Savanna 3 (ns3) & $08^{\circ} 19.661^{\prime} \mathrm{N} ; 001^{\circ} 51.340^{\prime} \mathrm{E}$ & 6.5 & 6.9 & 20.3 & 23.8 & 28.8 & 21.8 & 34.9 & 30.6 \\
\hline Yam field 1 (yfl) & $07^{\circ} 49.114^{\prime} \mathrm{N} ; 002^{\circ} 14.519^{\prime} \mathrm{E}$ & 6.1 & 6.5 & 9.3 & 9.9 & 8.7 & 6.1 & 8.7 & 8.7 \\
\hline Yam field 2 (yf2) & $07^{\circ} 55.111^{\prime} \mathrm{N} ; 002^{\circ} 10.507^{\prime} \mathrm{E}$ & 6.7 & 6.7 & 16.8 & 15.1 & 10.9 & 8.7 & 13.1 & 13.1 \\
\hline Yam field 3 (yf3) & $08^{\circ} 19.730^{\prime} \mathrm{N} ; 001^{\circ} 51.332^{\prime} \mathrm{E}$ & 6.2 & 6.3 & 6.4 & 7.5 & 6.5 & 3.9 & 8.7 & 13.1 \\
\hline
\end{tabular}

Soil samples were taken both during the wet season and dry season

w.s. wet season, d.s. dry season 
First trap culture experiment for AMF

Trap cultures were inoculated with aliquots of each of the replicate wet season soil samples per site. Four trap culture pots (pots $20 \times 20 \times 30 \mathrm{~cm}$ ) were established for each site, plus four non-inoculated control pots totaling 28 pots. For each pot, $4 \mathrm{~kg}$ of substrate was used, consisting of a sterilized 3:1 $(w / w)$ mixture of Terragreen ${ }^{\circledR}$ (a calcined granular Attapulgite clay mineral, American aluminum oxide, oil dry US special, type III R, $>0.125 \mathrm{~mm}$; Lobbe Umwelttechnik, Iserlohn, Germany) and quartz sand (Alsace quartz sand, 5\% of free silica, Smurfit Company, France), respectively. The chemical composition of the substrate was $0.3 \%$ organic matter, 10 and $1,480 \mathrm{mg} \mathrm{kg}^{-1}$ easily and slowly available $\mathrm{P}$ (extracted with sodium acetate and citrate), respectively, $191 \mathrm{mg} \mathrm{kg}^{-1}$ easily available potassium (extracted with sodium acetate), and a $\mathrm{pH}$ equal to 5.8. A 180-g sample of soil inoculum, divided into three equal sub-portions, was added to each pot, placed along three lines on the surface of $3 \mathrm{~kg}$ substrate and subsequently covered with the remaining $1 \mathrm{~kg}$ substrate. A 20 -mm thick drainage mat (Enkadrain ST; Colbond Geosynthetics, Arnhem, The Netherlands) was placed at the bottom of each pot. As bait plants, five $S$. guianensis and four $B$. humidicola plantlets were planted alternately and equidistantly above the three lines of inoculum. Automated watering systems (Tropf-Blumat; Weninger GmbH, Telfs, Austria) were used to irrigate the trap cultures, which were maintained in a greenhouse in Basel for 24 months under a day/night regime of $25 / 21^{\circ} \mathrm{C}$, with a photoperiod of at least $12 \mathrm{~h}$ (with supplementary artificial light depending on the season) and a mean relative humidity of $65 \pm 5 \%$. Trap plants were trimmed to $\sim 4 \mathrm{~cm}$ above the substrate level at 2-month intervals during the first year and 6-month intervals during the second.

Second trap culture experiment: including yam species as trap plants

In order to specifically detect those AMF associated with yam, a second trap culture experiment was set up using the dry-season soil samples as inocula and yam (D. rotundata cv TDr89/02461 and D. cayenensis cv TDc98-136) as well as $S$. bicolor as bait plants. The trap pots were established as above with a slight modification. Pots (1 L volume), were established using $800 \mathrm{~g}$ of substrate and $50 \mathrm{~g}$ of soil inoculum, and one plant per pot, to unequivocally attribute the sporulating AMF species to its host. In order to compare the two trap culture experiments, four additional pots inoculated per bait plant with wet season soil samples of field site yf2, were also included in this second experiment. Including four nonmycorrhizal controls per plant species, a total of 96 trap culture pots were established and maintained for 8 months, as above, with the exception that the bait plants were not trimmed during the experiment.

After 4, 6, and 8 months, and for the first trap culture experiment after 24 months, two separate soil cores (of $1.5 \mathrm{~cm}$ diameter, $10 \mathrm{~cm}$ depth) were removed from each pot to extract AMF spores and determine root colonization. For the trap cultures using yam as bait plants, yam shoot and tuber weights were recorded at 8 months.

Isolation and identification of AMF spores from field sites and trap cultures

AMF spores from field samples or from trap cultures were extracted by wet sieving and sucrose density gradient centrifugation after Oehl et al. (2003). For this purpose, $25 \mathrm{~g}$ air-dried field soil samples or $60 \mathrm{ml}$ trap culture substrate were suspended in $300 \mathrm{ml}$ of water using a $500-\mathrm{ml}$ beaker. The soil suspension was passed through 1,000-, $500-, 125-, 80-$, and $32-\mu \mathrm{m}$ nested sieves. The 1,000- and $500-\mu \mathrm{m}$ sieves were checked for sporocarps, spore clusters, and large spores and also on any roots present. The contents of the 125-, 80-, and 32- $\mu \mathrm{m}$ sieves were resuspended in a centrifuge tube, layered onto a water-sucrose solution $(70 \%$ $w / v)$ and centrifuged at 2,000 rpm for $2 \mathrm{~min}$. After centrifugation, the floating spores were collected by passing the supernatant through the $32-\mu \mathrm{m}$ sieve and rinsed with tap water. Spores, spore clusters, and sporocarps obtained from all sieves were transferred to Petri dishes and counted using a dissection microscope (Olympus SZ12) at up to $\times 90$ magnification. The spore density (= spore abundance) in a field sample was expressed as the number of AMF spores per gram soil (field samples) or per milliliter substrate (trap cultures).

For species identification, healthy spores were mounted on glass microscope slides with polyvinyl alcohol-lactic acid-glycerol (PVLG) or PVLG mixed 1:1 $(v / v)$ with Melzer's reagent (Brundrett et al. 1994). The spores were examined under a compound microscope (Zeiss, Axioplan) at up to $\times 400$ magnification. Identification was based on current species descriptions, identification manuals (Schenck and Pérez 1990, International Culture Collection of (Vesicular) Arbuscular Mycorrhizal Fungi, INVAM: http://invam.caf.wvu.edu), and own analyses on the type specimens of the large majority of AMF species (>95\%) deposited in the mycological herbaria of major relevance for the Glomeromycota (e.g., OSC, FH, Z+ZT, PDD, IBACC La Habana-Cuba, DPP). The relative abundance of each species was recorded on a scale: $<3 \%$ (rare); $3-20 \%$ (frequent); $>20 \%$ (abundant).

\section{Determination of AMF root colonization}

AMF root colonization was determined from trap cultures after 4 months of growth. The roots obtained upon wet 
sieving for spore isolation were collected with a forceps from a $50-\mu \mathrm{m}$ sieve and stained with Trypan blue according to Brundrett et al. (1994). After careful mycorrhizal root observation under a compound microscope at up to 200fold magnification, the gridline-intersect technique (after Giovannetti and Mosse 1980; Brundrett et al. 1994) was used to assess root colonization using a stereo microscope at up to 90-150-fold magnification.

Molecular identification of AMF in D. rotundata roots at field sites

Roots of $D$. rotundata were sampled from the field in the SGS in April 2007 to identify the AMF species actually colonizing yam in the field using a novel molecular technique. The roots analyzed derived from single plants of D. rotundata cv. kokoro and D. rotundata cv. kpakala cultivated near Toui Vap $\left(08^{\circ} 43.452^{\prime} \mathrm{N} ; 02^{\circ} 40.047^{\prime} \mathrm{E}\right)$, and from a $D$. rotundata cv. kokoro plant near Kilibo $\left(08^{\circ}\right.$ $42.106^{\prime} \mathrm{N}$; $02^{\circ} 40.544^{\prime} \mathrm{E}$ ). Newly formed roots were removed from freshly excavated mature $D$. rotundata tubers, carefully washed and chopped into ca. $1 \mathrm{~cm}$ length pieces all at site in the field. The pieces were then immediately crushed onto FTA $^{\circledR}$ cards (PlantSaver WB120065, Whatman International Ldt, Kent, UK) according to the manufacturer's indications and air-dried for about $30 \mathrm{~min}$. They were conveyed to the laboratory in Basel and stored at room temperature until further analyses.

In the laboratory, the cards were placed on a cutting mat, and single $2 \mathrm{~mm}$ diameter disks were removed from an area containing the absorbed sap that had been squeezed out from the roots, using a Harris Micro Punch ${ }^{\mathrm{TM}}$ (Whatman Inc. UK). Each disk was transferred to a 0.2-ml PCR tube and supplemented with $200 \mu \mathrm{l}$ of FTA $^{\circledR}$ Purification Reagent (Whatman International Ltd). The tube was sealed, inverted twice, and incubated for $5 \mathrm{~min}$ at room temperature. As much of the reagent as possible was then removed and the washing procedure with the FTA $^{\circledR}$ Purification Reagent repeated, followed by two washes with $200 \mu \mathrm{l}$ of $\mathrm{TE}_{0.1}$. The disks were then dried for $20 \mathrm{~min}$ at $56^{\circ} \mathrm{C}$.

The dry disks were immersed into a PCR mix containing Taq Polymerase from Amersham (Basel, Switzerland), $2 \mathrm{mM} \mathrm{MgCl} 2,0.5 \mu \mathrm{M}$ primers, $0.13 \mathrm{mM}$ of each desoxynucleoside triphosphate, and bovine serum albumin (BSA) at a concentration of $0.4 \mu \mathrm{g} \mu \mathrm{L}^{-1}$. PCR was carried out in a nested procedure as described by Redecker (2000). The first round of amplification was performed using the universal eukaryote primers NS5 and ITS4 in a $25 \mu \mathrm{l}$ assay. The cycling parameters were $94^{\circ} \mathrm{C}$ for $5 \mathrm{~min}, 30$ cycles of $94^{\circ} \mathrm{C}$ for $30 \mathrm{~s}, 51^{\circ} \mathrm{C}$ for $45 \mathrm{~s}, 72^{\circ} \mathrm{C}$ for $2 \mathrm{~min}$, and a final $5 \mathrm{~min}$ at $72^{\circ} \mathrm{C}$. The products were diluted $1: 10$ with sterilized double-distilled water and used as templates for the second PCR, which was conducted with Glomerales- specific primers (Redecker 2000). Annealing temperature was $61^{\circ} \mathrm{C}$ and PCR reactions were preheated to $61^{\circ} \mathrm{C}$ during sample loading to prevent nonspecific amplification. Positive PCR products were purified using the QuickClean 5 M PCR Purification Kit (GenScript Coporation, Piscataway, NY, USA) and cloned into a $\mathrm{PCR}^{\circledR} 4-\mathrm{TOPO}^{\circledR}$-Vector (Invitrogen, Basel, Switzerland). Representative clones were reamplified in a sequencing reaction, precipitated using BigDye X-Terminator (Applied Biosystems, Rotkreuz, Switzerland) and sequenced on a GeneticAnalyzer 3130 (Applied Biosystems, Rotkreuz, Switzerland). Sequences were edited in Sequence Navigator (version 1.0).

Partial Sequences of the $18 \mathrm{~S}$ ribosomal DNA were aligned to previously published sequences in PAUP* $4 \mathrm{~b} 10$ (Swofford 2001). The glomeromycotan origin of the sequences was initially tested with Blast (Altschul et al. 1997). Phylogenetic trees were obtained primarily by distance analysis (neighbor-joining algorithm) with PAUP* $4 \mathrm{~b} 10$ using the Kimura two parameter model and a gamma shape parameter of 0.5 . Results were verified by performing parsimony analyses. Since it is not possible for species in the Glomeromycota to assign a single sequence to a certain species or fungal isolate, sequence types were defined in a conservative manner as consistently separated phylogenetic clades/groups in the phylogenetic trees. The sequence phylotypes (st) were designated after their origin: West Africa (WA), the genus they belonged (e.g., Glomus = $\mathrm{Gl}$; Acaulospora $=\mathrm{Ac}$; Gigaspora $=\mathrm{Gi}$; Scutellospora $=\mathrm{Sc}$ ), and a numerical index of the sequence types within each genus (1-4), e.g., resulting in 'stWAGil'.

\section{Calculations and statistical analysis}

For the field sites, AMF spore density (number of spores per gram soil), and species richness (number of species detected) were recorded as average and total numbers per field site and sampling date and - if useful - as a sum of both dates. In the trap cultures, AMF spore density (number of spores per milliliter soil) and species richness were also recorded as average and total numbers per culture. The numbers of AMF species were determined from those that produced spores in the trap cultures inoculated with dry season field soils. For AMF root colonization, the mean percentage of colonized root length was recorded per site. Prior to further analysis, in order to provide homogeneity of variances, data on spores per gram soil (field) or per milliliter substrate (trap cultures) were $\log (x+1)$ transformed and AMF colonization $\arcsin (x / 100)$ transformed. Differences in spore density, species richness, and AMF root colonization between field sites were separated using Fisher's least significant difference (LSD) at $P \leq 0.05$ after one-way ANOVA analysis with SAS program, version 9.1 package (SAS Institute 2007). 


\section{Results}

AMF spores and species at field sites

The AMF spore density varied between $2-13$ and 3-17 spores $\mathrm{g}^{-1}$ soil in samples collected during the wet and the dry season, respectively (Fig. 1a, b). The spore density varied less between sites in the natural savannas than yam fields (6-11 versus $2-17$ spores $\mathrm{g}^{-1}$, respectively). No correlation was found between the spore density and any of the edaphic factors determined ( $\mathrm{pH}$, available $\mathrm{P}$, and organic $\mathrm{C}$; data not shown).

Overall, 40 AMF species belonging to ten genera and eight families were identified by morphotyping of spores isolated from the field samples (Table 2). Of these 40 species, 19 belonged to the Glomeraceae, nine to the Acaulosporaceae, five to the Racocetraceae (Oehl et al. 2008), and two each to Dentiscutataceae and Gigasporaceae

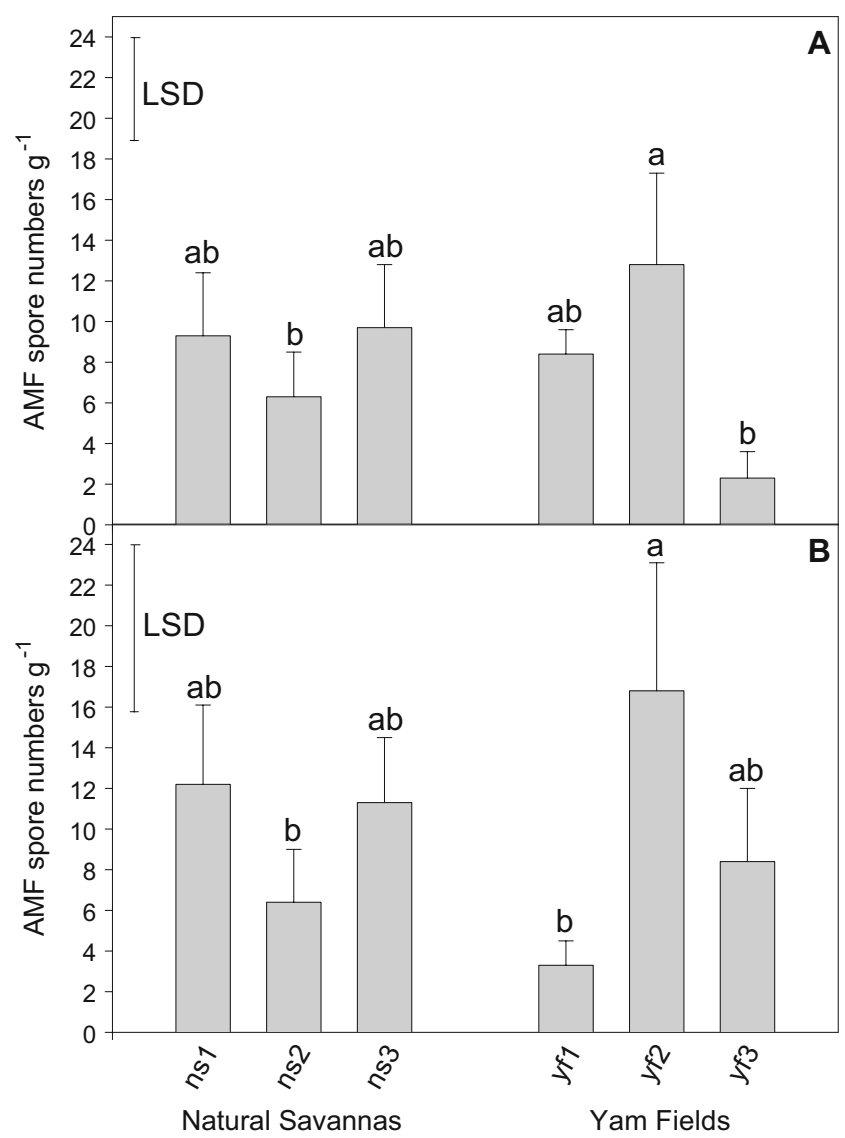

Fig. 1 AMF spore density (presented as spore numbers per gram in field soil samples) collected from natural savannas (ns1-3) and adjacent yam fields $(y f 1-3)$ in the Southern Guinea savanna of Benin in the wet season (September-October 2004, a) and in the subsequent dry season (February 2005, b). Data are reported as averages and standard deviations for four replicate plots per field site. Nonsignificant differences between sites are shown by identical letters, determined using Fisher's Least Significant Difference (LSD) at the $5 \%$ level following one-way ANOVA
(Oehl et al. 2008); the Entrophosporaceae, Paraglomeraceae, and Ambisporaceae were each represented by one species. Seven additional morphotypes could not be attributed to a described species (Table 2) and may represent new undescribed species (Glomus spp. WAGl1, WAGl2, WAGl3, WAG14, Acaulospora sp.WAAc1, Racocetra sp. WARa1, and Racocetra sp. WARa2).

The AMF species richness observed in the soil samples of the savannas was similar in the wet and dry season, whereas in the yam fields, it was higher in the wet than in the dry season samples (Fig. 2, Table 2). The cumulative species richness, comprising all the species detected in both the wet and dry season samples, was lower in yam fields than under natural savannas, indicating a change in the AMF community structure within the first year after slashand-burn (Fig. 2c). The species richness was not correlated with any of the edaphic factors analyzed $(\mathrm{pH}$, available $\mathrm{P}$ and organic $\mathrm{C}$; data not shown). Of the 40 species identified, 12 were found exclusively in the savanna samples and eight exclusively in the yam field samples. Glomus etunicatum and Acaulospora scrobiculata numerically dominated the spore populations in the yam fields, while various sporocarpic Glomus spp., such as $G l$. sinuosum, Gl. clavisporum, Gl. taiwanense, and Gl. pachycaulis were more frequently recovered from savanna soil than from yam fields and also Acaulospora species.

First trap culture experiment with wet season soil as AMF inoculum

In the trap cultures inoculated with wet season soils, AMF root colonization in $S$. guianensis and B. humidicola remained on an extremely low to insignificant level (0$5 \%$ ) during 8 months. Gl. etunicatum was almost the only species producing spores during the 8 months (sites ns1, yf1, and yf3) and in one yf3 pot, a few Gigaspora gigantea spores were additionally recovered, while in pots from ns2, ns3, and yf2, no sporulation was detected.

Second trap culture experiment preferably performed with dry season soil

Also in the second trap culture experiment, by using $D$. cayenensis, D. rotundata, and $S$. bicolor as bait plants, AM root colonization remained extremely low $(0-5 \%)$ after initial inoculation with wet-season soils (tested of yf2) and almost no spores were produced neither on the two yam species and $S$. bicolor nor with $S$. guianensis and $B$. humidicola as bait plants (data not shown). In contrast, all AMF communities established well in the trap cultures inoculated with dry-season soils and sporulated abundantly on all three bait plants used. Interestingly, despite a comparatively low AMF root colonization (10-20\%), S. bicolor 
Table 2 AMF species identified in soil sampled from three natural savannas (ns1-3) and three yam fields (yf1-3) during the wet season and subsequent dry season

\begin{tabular}{|c|c|c|c|c|c|c|c|c|c|c|c|c|}
\hline \multirow[t]{3}{*}{ AMF species } & \multicolumn{6}{|c|}{ Natural savannas } & \multicolumn{6}{|c|}{ Yam fields } \\
\hline & \multicolumn{2}{|l|}{ ns1 } & \multicolumn{2}{|l|}{$\mathrm{ns} 2$} & \multicolumn{2}{|l|}{ ns3 } & \multicolumn{2}{|l|}{ yf1 } & \multicolumn{2}{|l|}{ yf 2} & \multicolumn{2}{|l|}{ yf3 } \\
\hline & w.s & d.s. & w.s & d.s. & w.s & d.s. & w.s & d.s. & w.s & d.s. & w.s & d.s. \\
\hline \multicolumn{13}{|l|}{ Glomeraceae } \\
\hline Glomus etunicatum & $\bullet$ & $\bullet$ & $\bullet$ & $\bullet$ & $\bullet$ & $\bullet$ & $\Delta$ & $\Delta$ & $\Delta$ & $\Delta$ & $\Delta$ & $\Delta$ \\
\hline Gl. macrocarpum & $\bullet$ & $\bullet$ & $\bullet$ & $\bullet$ & $\bullet$ & $\bullet$ & $\bullet$ & $\bullet$ & $\bullet$ & $\bullet$ & $\bullet$ & $\bullet$ \\
\hline Gl. intraradices & $\bullet$ & $\bullet$ & $\bullet$ & $\bullet$ & $\bullet$ & & $\bullet$ & $\bullet$ & & & & \\
\hline Gl. sinuosum & $\bullet$ & $\bullet$ & & & $\bullet$ & & & & $\circ$ & & & $\circ$ \\
\hline Gl. brohultii & $\bullet$ & $\bullet$ & & & $\bullet$ & & & & & $\bullet$ & & \\
\hline Gl. constrictum & $\bullet$ & & $\bullet$ & & $\bullet$ & & & & ○ & & $\circ$ & \\
\hline Gl. clavisporum & & & $\bullet$ & $\bullet$ & $\bullet$ & & & & $\circ$ & & & \\
\hline Gl. taiwanense & & & $\bullet$ & & & $\bullet$ & & & $\circ$ & & & \\
\hline Gl. sp. WAG12 ${ }^{\mathrm{a}}$ & $\bullet$ & & & & & & & & & & $\circ$ & \\
\hline Gl. sp. WAGl $4^{\mathrm{b}}$ & $\bullet$ & & - & & $\circ$ & & & & & & & \\
\hline Gl. pachycaulis & $\bullet$ & $\bullet$ & & & & & & & & & & \\
\hline Gl. versiforme & & & & ○ & & $\circ$ & & & & & & \\
\hline Gl. hoi & & & & $\circ$ & & $\circ$ & & & & & & \\
\hline Gl. mosseae & & & & $\circ$ & & $\circ$ & & & & & & \\
\hline Gl. sp. WAG13 & & & & & $\circ$ & $\circ$ & & & & & & \\
\hline Gl. ambisporum & & & & & & & & & & & $\circ$ & \\
\hline Gl. fasciculatum & & & & & & & & & & ० & & \\
\hline Gl. claroideum & & & & & & & & & & & $\circ$ & \\
\hline Gl. sp. WAGl1 ${ }^{\mathrm{c}}$ & & & & & & & & & & & & ० \\
\hline
\end{tabular}

Acaulosporaceae

Acaulospora sp. WAAc1 ${ }^{\mathrm{d}}$

Ac. scrobiculata

Ac. spinosa

Ac. mellea

Ac. laevis

Ac. excavata

Ac. elegans

Ac. morrowiae

Kuklospora colombiana

Entrophosporaceae

Entrophospora infrequens

Gigasporaceae

Gigaspora decipiens

Gi. gigantea

Racocetraceae

Racocetra fulgida

Racocetra sp. WASc1

Racocetra sp. WASc2

$R a$. verrucosa

Cetraspora pellucida

Dentiscutataceae

Fuscutata heterogama

Fu. savannicola

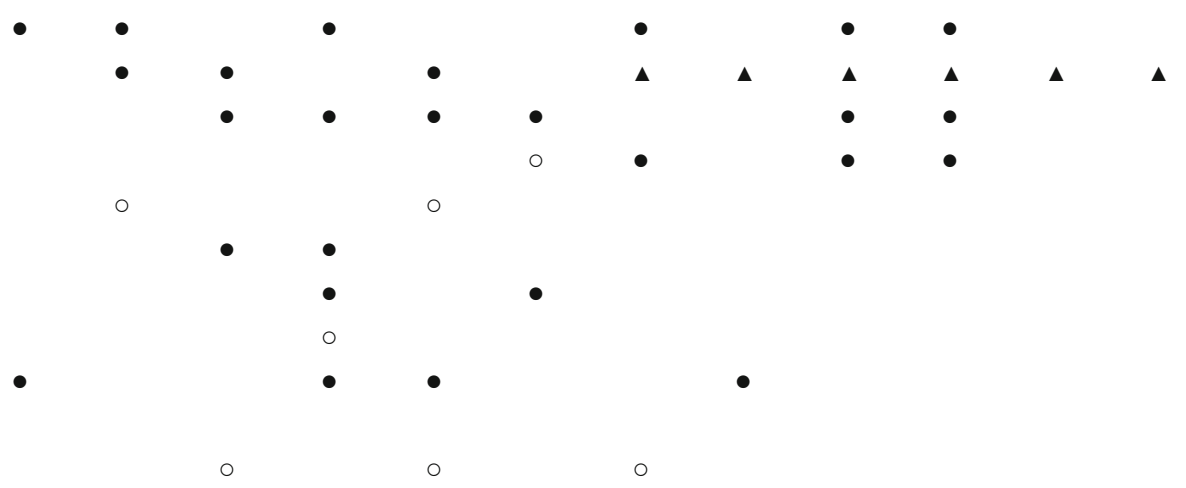


Table 2 (continued)

\begin{tabular}{|c|c|c|c|c|c|c|c|c|c|c|c|c|}
\hline \multirow[t]{3}{*}{ AMF species } & \multicolumn{6}{|c|}{ Natural savannas } & \multicolumn{6}{|c|}{ Yam fields } \\
\hline & \multicolumn{2}{|l|}{ ns1 } & \multicolumn{2}{|l|}{ ns2 } & \multicolumn{2}{|l|}{ ns3 } & \multicolumn{2}{|l|}{ yf1 } & \multicolumn{2}{|l|}{ yf2 } & \multicolumn{2}{|l|}{ yf3 } \\
\hline & w.s & d.s. & w.s & d.s. & w.s & d.s. & w.s & d.s. & w.s & d.s. & W.s & d.s \\
\hline \multicolumn{13}{|l|}{ Paraglomeraceae } \\
\hline Paraglomus occultum & & $\circ$ & & & & ○ & & ○ & & & & \\
\hline \multicolumn{13}{|l|}{ Ambisporaceae } \\
\hline Ambispora gerdemannii & & & & ○ & $\circ$ & & & & & ○ & & \\
\hline Total species numbers & 14 & 14 & 13 & 17 & 16 & 13 & 14 & 9 & 12 & 10 & 9 & 6 \\
\hline Total species numbers per site & 18 & & 23 & & 25 & & 16 & & 15 & & 11 & \\
\hline Total species numbers per system & 32 & & & & & & 28 & & & & & \\
\hline Total species numbers in field samples & 40 & & & & & & & & & & & \\
\hline
\end{tabular}

Please note that according to the authors' analyses, Gl. pachycaulis and Gl. rubiforme are not conspecific relying on the type specimens and original species descriptions and illustrations of both species. The relative abundance of each AMF species was recorded following the scale: (rare): $\circ,<3 \%$ or only a few specimens found; (frequent): $\bullet, 3-20 \%$; (abundant): $\mathbf{\Lambda},>20 \%$

$n s$ natural savanna, $y f$ yam field, w.s. wet season, d.s. dry season

${ }^{\text {a }}$ Resembling Gl. halonatum

${ }^{\mathrm{b}}$ Resembling Gl. aureum

${ }^{\mathrm{c}}$ Resembling Gl. rubiforme

${ }^{\mathrm{d}}$ Resembling Ac. rehmii

induced a much higher spore production in the trap cultures (12-94 spores $\mathrm{mL}^{-1}$ ) than the highly AMF-colonized yam (D. cayenensis and D. rotundata, 70-95\%), which produced 0.1-17 and 1-34 spores $\mathrm{mL}^{-1}$, respectively (Figs. 3 and 4).

In the trap cultures inoculated with dry season soils, 45 AMF species, representing ten genera and eight families were identified (Table 3). The majority of the species belonged to the Glomeraceae (22 spp.) followed by the Acaulosporaceae (16 spp.), Racocetraceae (two spp.), Gigasporaceae, Ambisporaceae, Archaeosporaceae, Entrophosporaceae, and Paraglomeraceae (one sp. each). Of the 45 species (or morphotaxa) recorded, 16 could not be identified from the field samples (Table 2). These were mainly species forming small and rapidly degraded spores, such as Gl. eburneum, Ac. undulata, and Intraspora schenkii or species such as Gl. aggregatum, Kuklospora kentinensis, and $K u$. colombiana, which are usually difficult to distinguish from similar looking species such as $G l$. intraradices, Ac. scrobiculata, and Ac. dilatata, respectively) in field samples. Of the species detected in the field samples, 11 were not found in the trap cultures, especially sporocarpic Glomus spp., such as Gl. pachycaulis and above all, several Gigaspora, Racocetra, and Fuscutata spp. Twenty-nine species were detected in trap cultures from both savannas and yam fields, whereas eight species were exclusively from savanna and eight exclusively from yam field trap cultures (Table 3). The AMF species sporulating fastest and most abundantly were $G$ l. etunicatum and Ac. scrobiculata in the majority of the trap cultures.
These two species had also produced a greater absolute and relative spore density in the yam fields than in the savannas (Table 2).

AMF species associated with yam

After 8 months trap culturing with yam, AMF spores of 37 spp. were detected in total (Table 3). Of these, $29 \mathrm{spp}$. were associated with $D$. cayenensis and 28 with $D$. rotundata, with $20 \mathrm{spp}$. common to both plant species. From the trap cultures using S. bicolor, a total of $37 \mathrm{spp}$. were found associated, of which four were not recovered from the yam cultures. The mean species richness detected per site was also higher in the trap cultures with $S$. bicolor (8-11) than in those with $D$. cayenensis (4-7) or D. rotundata (3-8; Fig. 5).

Trap cultures using yam as bait plants produced AMF spores from seven families. Approximately half of these were Glomeraceae (18 Glomus spp.), followed by the Acaulosporaceae (12 Acaulospora spp. and one Kuklospora sp.). Furthermore, spores of Racocetra fulgida, Gi. gigantea, Entrophospora infrequens, Paraglomus occultum, and Intraspora schenckii were recovered (Table 3).

Overall AMF detected by spore morphotyping from both field and trap culture samples

Considering both field and trap culture results, a total of 56 species were detected across sites (Table 4) with a similar 


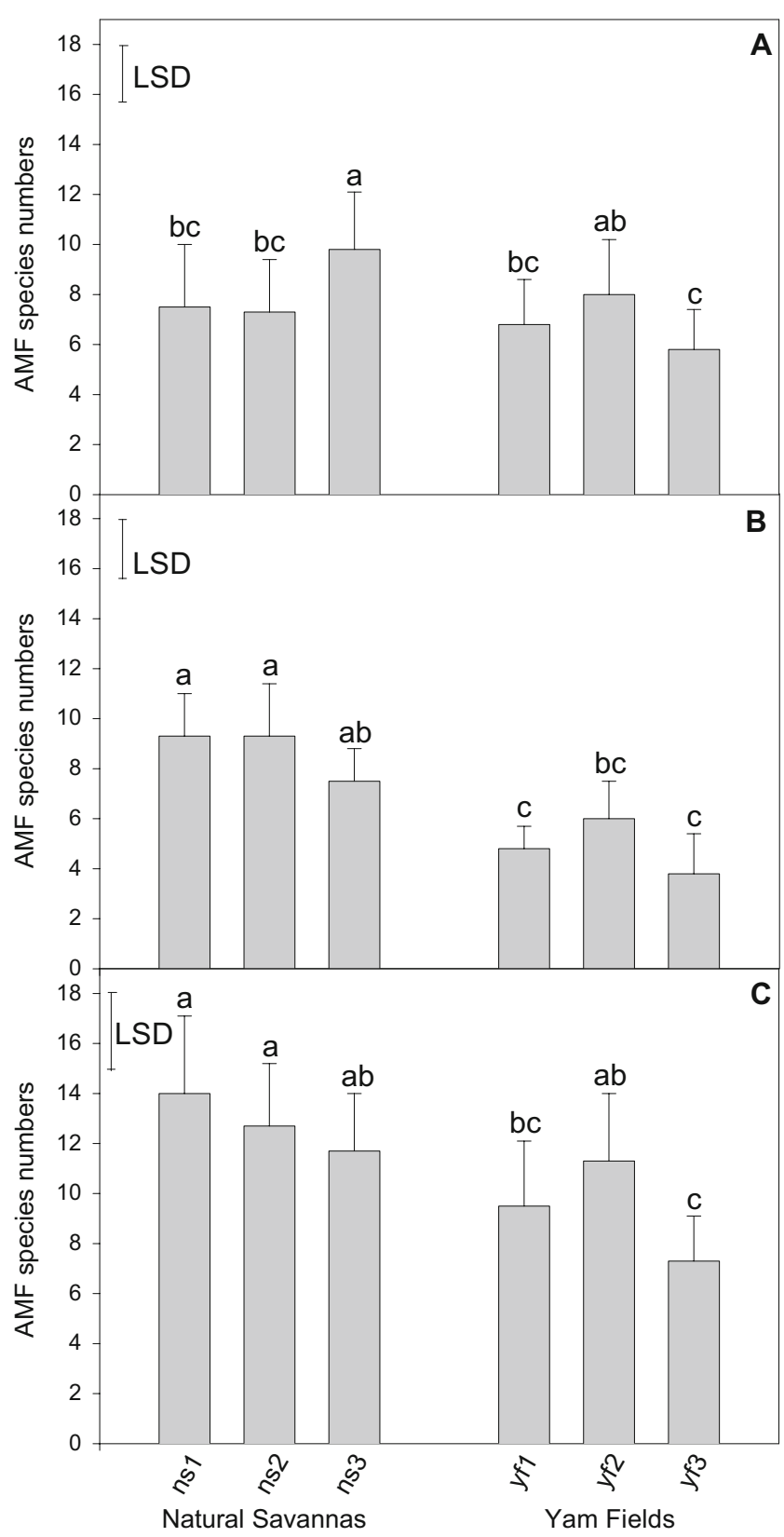

Fig. 2 AMF species richness in field soil samples collected from natural savannas (ns1-3) and adjacent yam fields $(y f 1-3)$ in the Southern Guinea savanna of Benin in the wet season (SeptemberOctober 2004, a) and in the subsequent dry season (February 2005, b) and cumulative from both seasons (c). Data are reported as averages and standard deviations for four replicate plots per field site. Nonsignificant differences between sites are shown by identical letters, determined using Fisher's Least Significant Difference (LSD) at the 5\% level following one-way ANOVA

total species richness recovered from savanna $(29,33$, and 36 ; overall 45$)$ and yam sites $(29,30$, and 35 ; overall 45$)$. The mean species richness was, however, slightly higher in the savanna $(20,21)$ than the yam sites $(17-19)$ a result which, however, became statistically significant only when the data of all three savanna respective yam sites were pooled together.
Molecular identification of AMF species colonizing yam roots collected at field sites

The molecular analyses, performed on roots sampled from the field in the SGS in April 2007, were based on partial

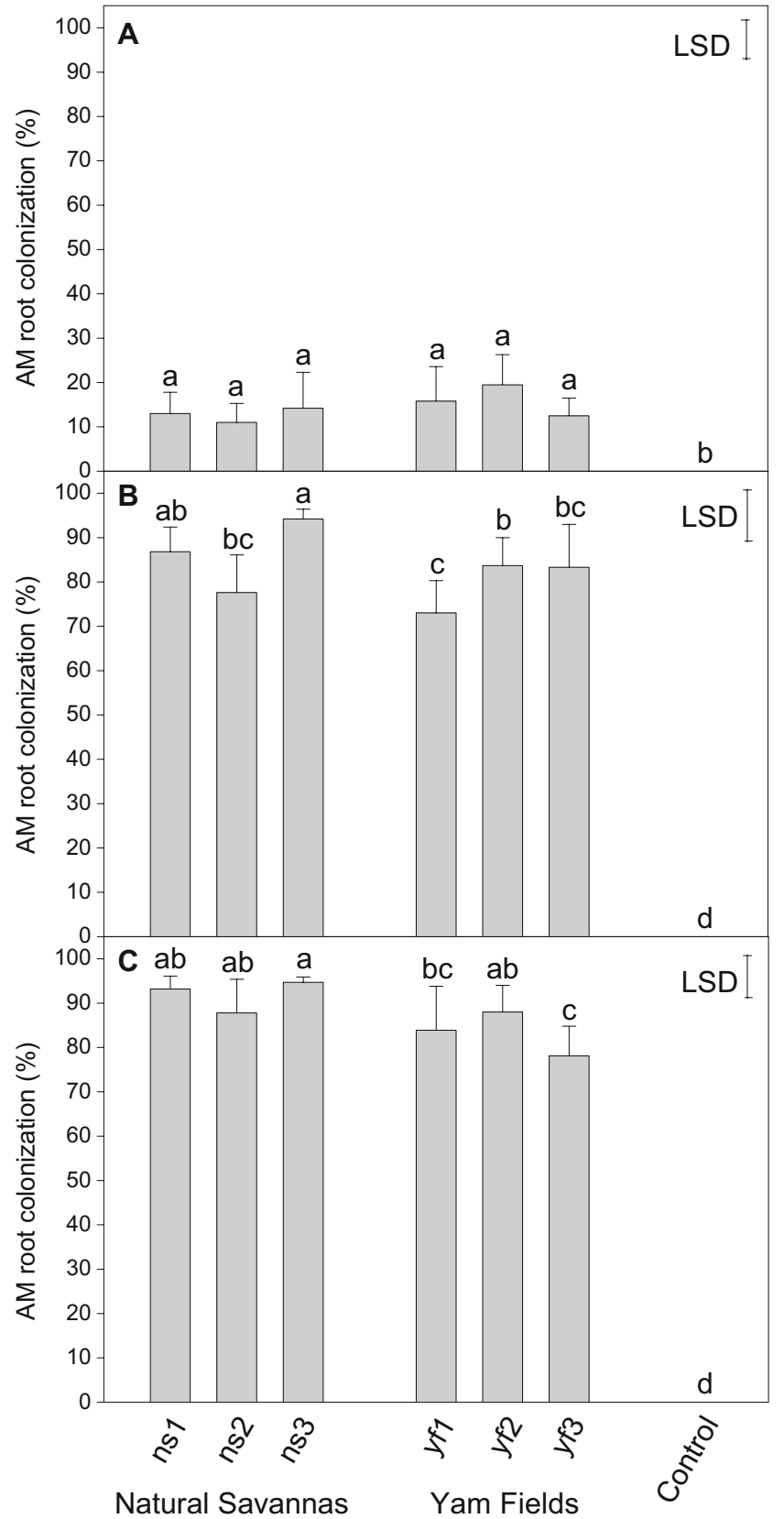

Fig. 3 AMF root colonization (\%) of S. bicolor (a), D. cayenensis (b), and D. rotundata (c) following 4 months cultivation in trap cultures using dry season field soils from three natural savannas ( $n s 1-$ 3) and adjacent yam fields (yfl-3) as inocula and including a nonmycorrhizal control. Data are reported as averages and standard deviations for four replicate plots per field site. Nonsignificant differences between sites are shown by identical letters, determined using Fisher's Least Significant Difference $(L S D)$ at the 5\% level following one-way ANOVA 


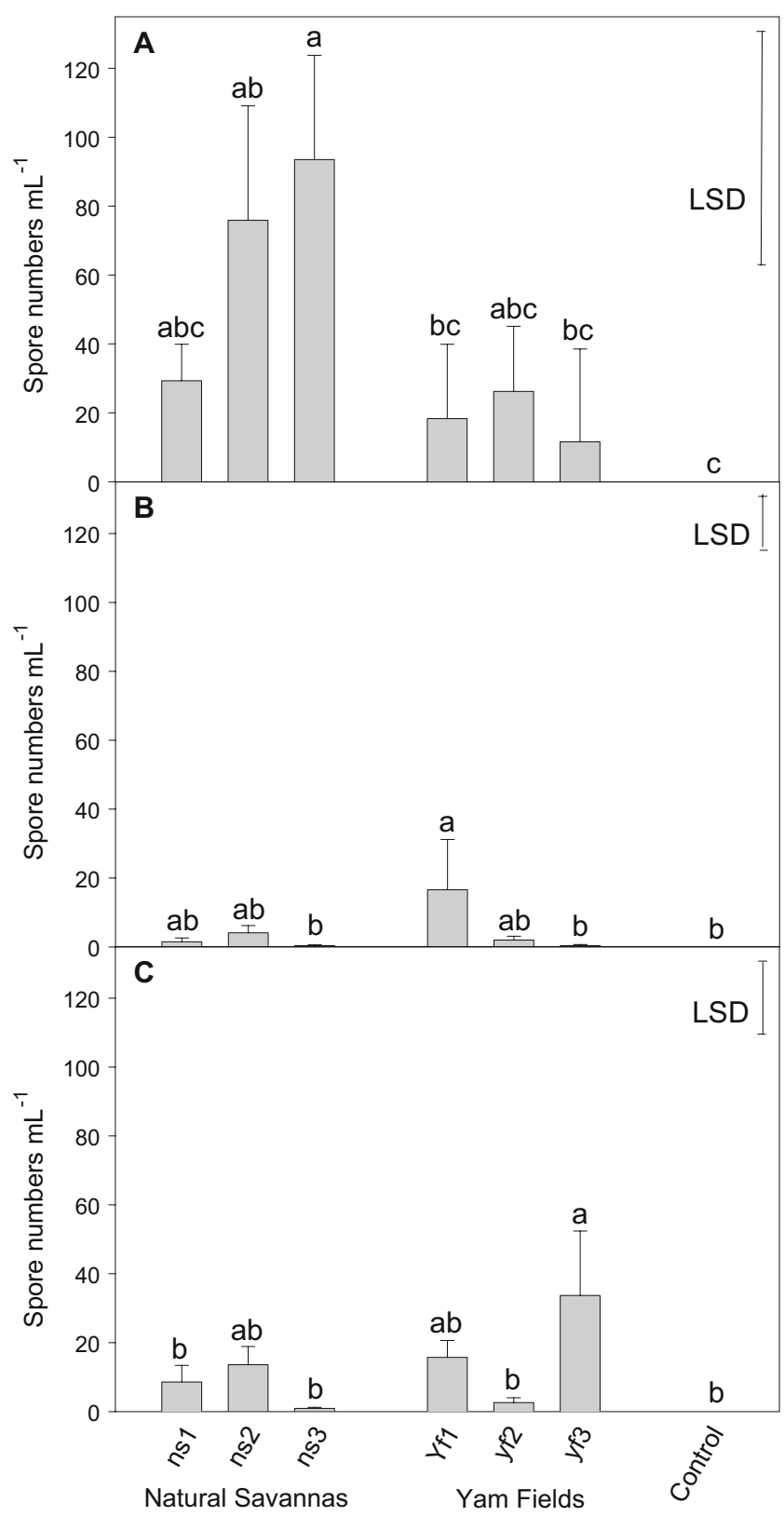

Fig. 4 AMF spore density (presented as spore numbers per milliliter of substrate) on $S$. bicolor (a), D. cayenensis (b) and D. rotundata (C) following four months cultivation in trap cultures using dry season field soils from three natural savannas $(n s 1-1)$ and adjacent yam fields $(y f 1-3)$ as inocula, and including a nonmycorrhizal control. Data are reported as averages and standard deviations for four replicate plots per field site. Nonsignificant differences between sites are shown by identical letters, determined using Fisher's Least Significant Difference $(L S D)$ at the $5 \%$ level following one-way ANOVA

$18 \mathrm{~S}$ ribosomal gene sequences analyzed in field collected yam roots $(D$. rotundata) using a novel technique for DNA extraction and preservation. The technique has the advantage that DNA can be extracted from the roots and concentrated on filter cards directly in the field, and the immediately air-dried DNA can easily be preserved on the cards for several months under room temperature before further analyses will be performed. Phylogenetic grouping revealed that the AMF sequence types (st) detected fell into the five AMF genera that dominated the spore populations assessed from the field sites: Glomus, Acaulospora, Cetraspora, Racocetra, and Gigaspora (Fig. 6). Most st were closely related to sequences of species already found by spore morphotyping from the six field sites under study, e.g., stWAGl1 related to Gl. constrictum, stWAGl2 related to Gl. clarum, stWAGl3 to Gl. sinuosum, stWAAc1 related to Ac. spinosa and related species, stWAGil related to $G i$. gigantea and related species, stWACe1a and stWACe1b related to Ce. pellucida and related species, and stWARa4 related to Ra. fulgida sequences (Fig. 6). However, the sequence types obtained could also belong to unknown species related to known species; a clear attribution is not even allowed for stWAGl3, forming a clade with $G l$. sinuosum with a high bootstrap support (96, Fig. 6). One st (stWARa2) could not at all be related to sequences of a known species, but we suspect that these sequences belong to Racocetra sp. WARa1 or Ra. sp. WARa2 (Table 2) or a closely related, described, or undescribed Racocetra species, since this st groups within sequences of this new genus. However, the data clearly show that AMF species of at least five different genera actually colonized the yam roots in the field.

Effect of the soil inocula on yam development

The different soil inocula originating from the savanna and yam field sites did not influence yam shoot growth in the trap cultures compared with non-mycorrhizal controls (Fig. 7). However, D. rotundata tuber weights were, on average, $40 \%$ heavier than the controls in pots inoculated with soil derived from three sites (ns1, ns2 and yf3; Fig. $8 \mathrm{~b}$ ). In the case of $D$. cayenensis, tuber weights were approximately $20 \%$ heavier than non-inoculated controls across treatments, although only for the ns1 site was the effect significant $(P<0.05$; Fig. 8a).

\section{Discussion}

From only a relatively small number of sites in the SGS of Benin in West Africa, under natural savanna and adjacent yam fields, extensive spore morphotyping resulted in the detection of totally 56 AMF species. Such species diversity in a restricted area indicates a huge AMF species richness in West African soils, especially when compared with similar studies from other tropical ecosystems (e.g., Sanginga et al. 1999; Dalpé et al. 2000; Lekberg et al. 2007; Mathimaran et al. 2007; reviews by Öpik et al. 2006 and Gai et al. 2006). Using molecular identification tools, 
Table 3 AMF species recovered from trap cultures using Sorghum bicolor, Dioscorea cayenensis, and Dioscorea rotundata as bait plants and inoculated with soil sampled during the dry season from natural savanna and yam field sites

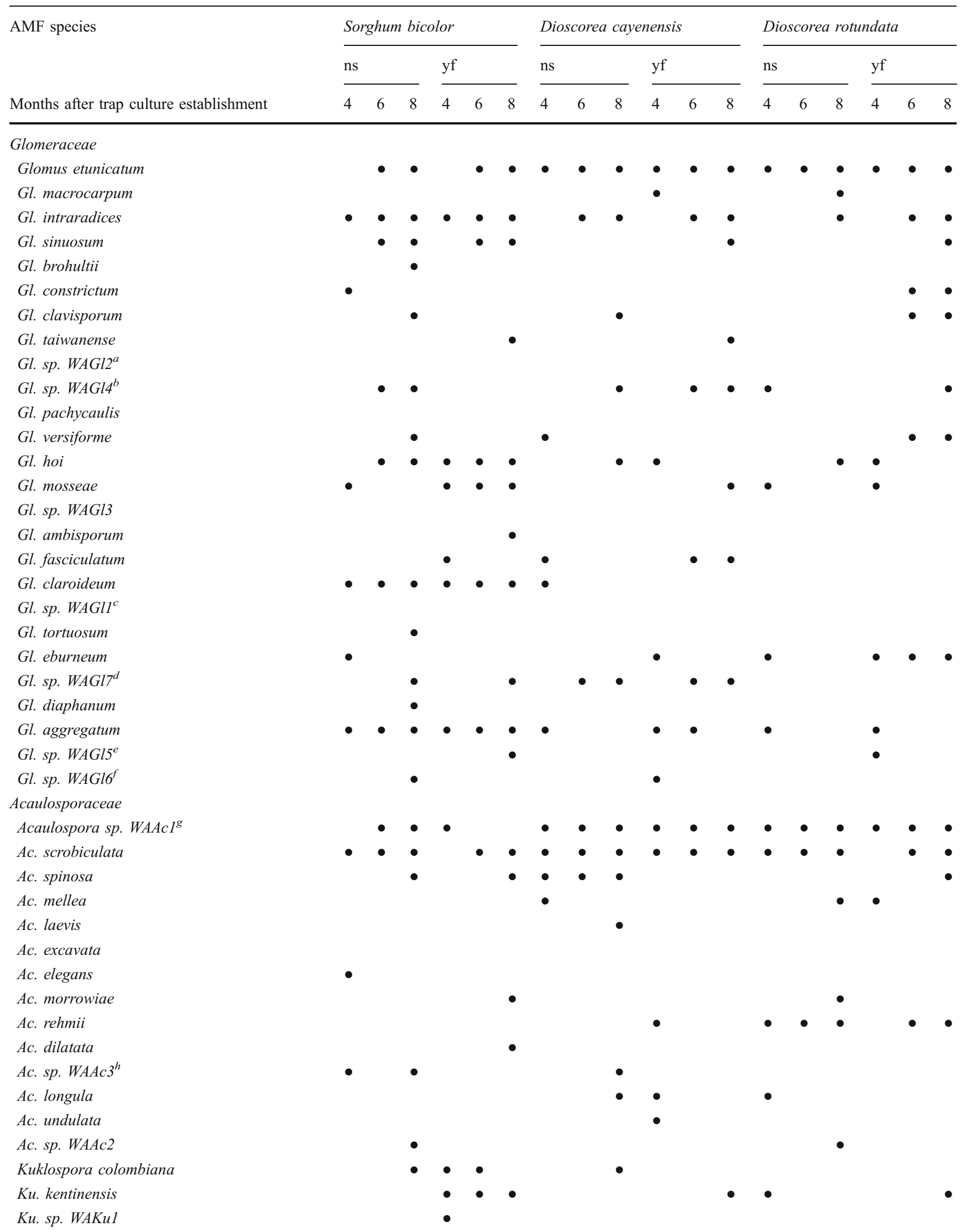

Ku. sp. WAKu1 
Table 3 (continued)

\begin{tabular}{|c|c|c|c|c|c|c|c|c|c|c|c|c|c|c|c|c|c|c|}
\hline \multirow{3}{*}{$\begin{array}{l}\text { AMF species } \\
\text { Months after trap culture establishment }\end{array}$} & \multicolumn{6}{|c|}{ Sorghum bicolor } & \multicolumn{6}{|c|}{ Dioscorea cayenensis } & \multicolumn{6}{|c|}{ Dioscorea rotundata } \\
\hline & \multicolumn{3}{|l|}{$\mathrm{ns}$} & \multicolumn{3}{|l|}{ yf } & \multicolumn{3}{|l|}{ ns } & \multicolumn{3}{|l|}{ yf } & \multicolumn{3}{|l|}{ ns } & \multicolumn{3}{|l|}{ yf } \\
\hline & 4 & 6 & 8 & 4 & 6 & 8 & 4 & 6 & 8 & 4 & 6 & 8 & 4 & 6 & 8 & 4 & 6 & 8 \\
\hline \multicolumn{19}{|l|}{ Entrophosporaceae } \\
\hline Entrophospora infrequens & & $\bullet$ & & & & & $\bullet$ & $\bullet$ & $\bullet$ & & & & $\bullet$ & $\bullet$ & $\bullet$ & & & \\
\hline \multicolumn{19}{|l|}{ Gigasporaceae } \\
\hline \multicolumn{19}{|l|}{ Gigaspora decipiens } \\
\hline Gi. gigantea & & & & $\bullet$ & & & & & & & & & & & & & & $\bullet$ \\
\hline \multicolumn{19}{|l|}{ Racocetraceae } \\
\hline Racocetra fulgida & $\bullet$ & & & & & & & & & $\bullet$ & & & & & & & & \\
\hline \multicolumn{19}{|l|}{ Racocetra sp. WAScl } \\
\hline \multicolumn{19}{|l|}{ Racocetra sp. WASc2 } \\
\hline \multicolumn{19}{|l|}{ Ra. verrucosa } \\
\hline Cetraspora pellucida & & & & & & & & & & & & & & & $\bullet$ & & & \\
\hline \multicolumn{19}{|l|}{ Dentiscutataceae } \\
\hline \multicolumn{19}{|l|}{ Fuscutata heterogama } \\
\hline \multicolumn{19}{|l|}{ Fu. savannicola } \\
\hline \multicolumn{19}{|l|}{ Paraglomeraceae } \\
\hline Paraglomus occultum & $\bullet$ & $\bullet$ & $\bullet$ & $\bullet$ & $\bullet$ & $\bullet$ & $\bullet$ & $\bullet$ & $\bullet$ & $\bullet$ & $\bullet$ & $\bullet$ & $\bullet$ & $\bullet$ & $\bullet$ & $\bullet$ & $\bullet$ & $\bullet$ \\
\hline \multicolumn{19}{|l|}{ Ambisporaceae } \\
\hline Ambispora gerdemannii & & & & - & & & & & & & & & & & & & & \\
\hline \multicolumn{19}{|l|}{ Archaeosporaceae } \\
\hline Intraspora schenckii & $\bullet$ & & & & & & & & & & & & & & & $\bullet$ & & \\
\hline Number of species per system and trap plant & 29 & & & 23 & & & 19 & & & 21 & & & 20 & & & 22 & & \\
\hline Number of species per plant species & 37 & & & & & & 29 & & & & & & 28 & & & & & \\
\hline Total number of species in trap cultures & 45 & & & & & & & & & & & & & & & & & \\
\hline
\end{tabular}

Spores were identified at 4, 6, and 8 months of trap culturing. $\bullet$ - the sampling period at which spores of respective species were detected

${ }^{\text {a }}$ Resembling Gl. halonatum

${ }^{\mathrm{b}}$ Resembling Gl. aureum

${ }^{\mathrm{c}}$ Resembling Gl. rubiforme

${ }^{\mathrm{d}}$ Resembling Gl. tenue

${ }^{\mathrm{e}}$ Resembling Gl. tortuosum

${ }^{\mathrm{f}}$ Resembling Gl. arborense

${ }^{\mathrm{g}}$ Resembling Ac. rehmii

${ }^{\mathrm{h}}$ Resembling Ac. elegans

Husband et al. (2002) recorded 30 AMF taxa from three sites in tropical savannas of Panama. The high AMF species richness demonstrated in our study could partly be attributed to the sampling of soils at two separate occasions in different seasons. It is also probably a result of the combination of the methods employed to detect spores, including direct spore detection in fresh field samples, trap cultures using different host plants, and use of molecular techniques. In a previous AMF study of multiple field sites under different land use intensities within two eco-climatic zones, the Southern and Northern Guinea savannas in Benin, 35 and 39 AMF species, respectively, were detected in the soils sampled during the wet season (Tchabi et al. 2008), reflecting present field sample results (40 species). In this respect, it is remarkably that several AMF species - so far known only from the tropical Americas - have been confirmed from Benin, which is in accordance with the facts that AM fungi are much older (about 400-450 Ma) than the separation of Southern and Central America from Western Africa (about $100 \mathrm{Ma}$ ) and that important migrations of people and transfer of plant species took place between these continents during the last centuries (Oehl et al. 2007).

The trap cultures inoculated with soil collected during the dry season yielded a multitude of AMF species, 


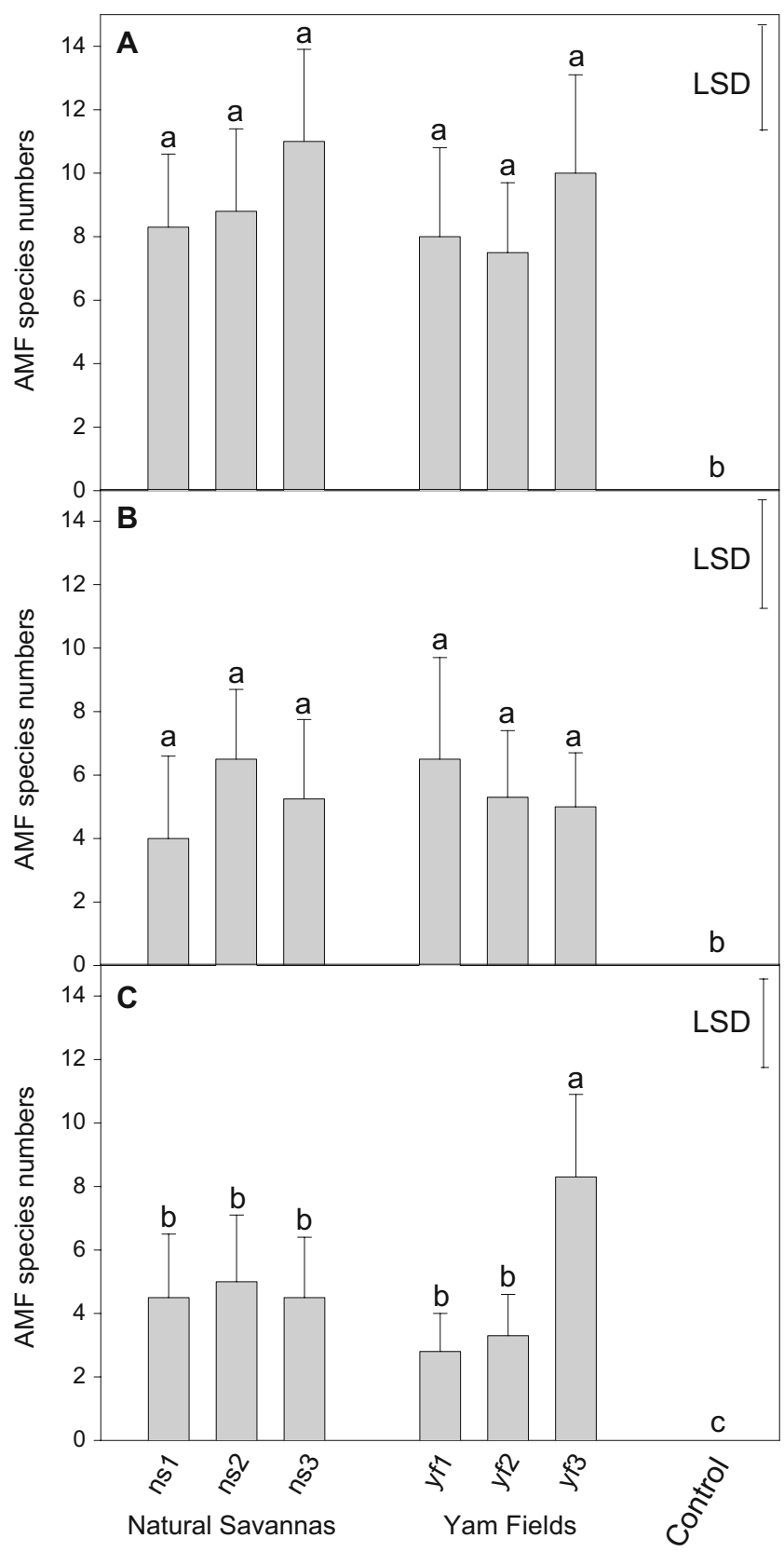

Fig. 5 AMF species richness on S. bicolor (a), D. cayenensis (b), and D. rotundata (c) following 4 months cultivation in trap cultures using dry season field soils from three natural savannas (ns1-3) and adjacent yam fields $(y f 1-3)$ as inocula and including a nonmycorrhizal control. Data are reported as averages and standard deviations for four replicate plots per field site. Nonsignificant differences between sites are shown by identical letters, determined using Fisher's Least Significant Difference $(L S D)$ at the $5 \%$ level following one-way ANOVA

compared with the very poor yield obtained with trap cultures inoculated with wet season soils. This could result from increased exposure of AMF spores to fungivorous nematodes, colembollans, and microbial antagonists under humid soil conditions in wet season soils (Klironomos et al.
1999; Bakhtiar et al. 2001; Tiunov and Scheu 2005; Tchabi 2008). Moreover, many AMF species may complete their life cycle with sporulation only towards the end of the wet season, for survival during the "off" (dry) season, with newly formed spores often becoming dormant. Consequently, our study indicates and strongly recommends that for successful trapping of AMF from such tropical ecosystems, soil sampling should be performed during the dry season. Nevertheless, despite our intensive search with repeated sampling and trap culturing, we assume that there remain additional AMF species in these ecosystems, undetected through limited or no sporulation, both in the field soils and in the trap cultures.

The current study documents for the first time that yam is associated with a plethora of AMF species and that when using yam as bait plants in trap cultures, the roots rapidly become highly colonized by a multitude of AMF species. With $D$. cayenensis and D. rotundata, the number of AMF species detected by spore morphotyping steadily increased over time in the trap cultures, with one species ( $G l$. etunicatum) appearing already 2 months after inoculation and up to 29 species after 8 months. Similarly, Oehl et al. (2003) and Chaurasia and Khare (2005) observed an increasing number of species sporulating in trap cultures over a period of 20 months. In the present study, some species consistently sporulated faster than others in trap cultures, particularly Gl. etunicatum and Ac. scrobiculata, on both yam cultivars and sorghum. These two AMF species also tended to dominate the spore populations observed in the soil samples from the yam field sites. The fact that especially $G l$. etunicatum belonging to Glomus group B sensu Schuessler et al. was not detected through molecular analyses might be due to the fact that such species might be able to rapidly reproduce spores but might not necessarily colonize the roots on a significant respective detectable level (e.g., Oehl et al. 2003, 2004).

From the sorghum trap cultures several AMF species were recovered which were not detected with yam, whereas other species were recovered exclusively with yam. Even among the yam cultivars, some AMF species were recovered only with $D$. rotundata and others only with $D$. cayenensis. This could be indicative of a certain host specificity of these AMF spp, although we did not additionally assess such a possible specificity during this study. AMF host specificity, or rather preference, has been observed with other crops (e.g., Bever et al. 1996, 2001; Sýkorová et al. 2007). Lovelock et al. (2003) discovered differences in relative spore density of AMF communities depending on the host plants used, and Vandenkoornhuyse et al. (2002) observed that the AMF community colonizing Trifolium repens differed from that in neighboring Agrostis capillaris. Such host preferences have obvious implications for establishing efficient and comprehensive AMF trap 
Table 4 AMF species richness for three natural savanna sites (ns1-ns3) and three adjacent yam fields (yf1-yf3) identified by spore morpho-typing

\begin{tabular}{|c|c|c|c|c|c|c|c|}
\hline & \multicolumn{3}{|c|}{ Natural savannas } & \multicolumn{3}{|c|}{ Yam fields } & \multirow[t]{2}{*}{$L S D$} \\
\hline & ns 1 & ns2 & ns 3 & yf1 & yf2 & yf3 & \\
\hline AMF species richness (mean of four replicate plots) ${ }^{\mathrm{a}}$ & $20.5 \mathrm{a}$ & $20.3 \mathrm{a}$ & $20.0 \mathrm{a}$ & $19.3 \mathrm{a}$ & $17.3 \mathrm{a}$ & $16.8 \mathrm{a}$ & 3.9 \\
\hline AMF species richness (sum of four replicate plots) & 29 & 36 & 33 & 29 & 35 & 30 & - \\
\hline Total AMF species richness per (agro-)ecosystem & 45 & & & 45 & & & \\
\hline Total AMF species richness in study area & 56 & & & & & & \\
\hline
\end{tabular}

Data combined for field site and trap culture results

${ }^{a}$ Average of four replicate plots per field site. Non-significant differences between sites are shown by identical letters and were determined by Fisher's Least Significant Difference $(L S D)$ at the 5\% level after one-way ANOVA

cultures, especially for studying AMF communities in ecosystems (Oehl et al. 2003).

AMF root colonization in the trap cultures was markedly higher for yam than for sorghum. A high level of AMF colonization of yam has also been reported from the field, although this varied with yam genotype (IITA 2005). The high level of yam root colonization could be associated with low yam root density, compared to the extensive root
Fig. 6 Phylogenetic tree of Glomeromycota obtained by neighbor-joining analysis of 310 characters of the $18 \mathrm{~S}$ rDNA subunit. Numbers above branches denote bootstrap values from 1,000 replications for neighbor-joining and for parsimony. The tree was rooted with $P a$. occultum. Sequences obtained in the present study from $D$. rotundata roots are shown in boldface. They are attributed to AM fungi on the genus level (e.g., Gl. sp. for Glomus) and are additionally labeled with the database accession number (e.g., AJ206343). The sequence types (st, e.g. stWAGl1) are labeled with the continent of origin ( $W A=$ West Africa), the genus abbreviation (e.g. $G l$ for Glomus) and the numerical index of the st within the genus (1-4). The brackets show the delimitation of the nine (ten) sequence types

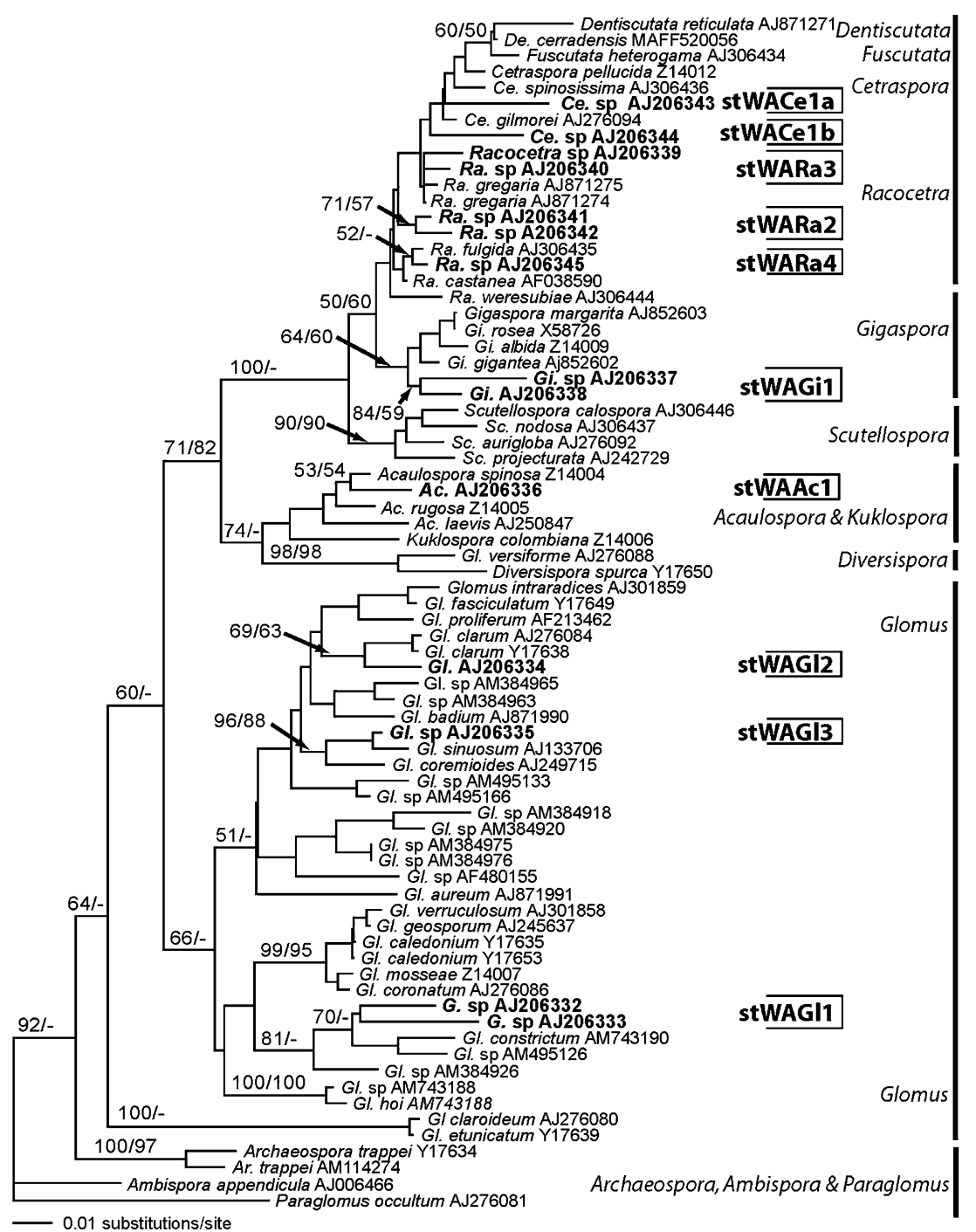




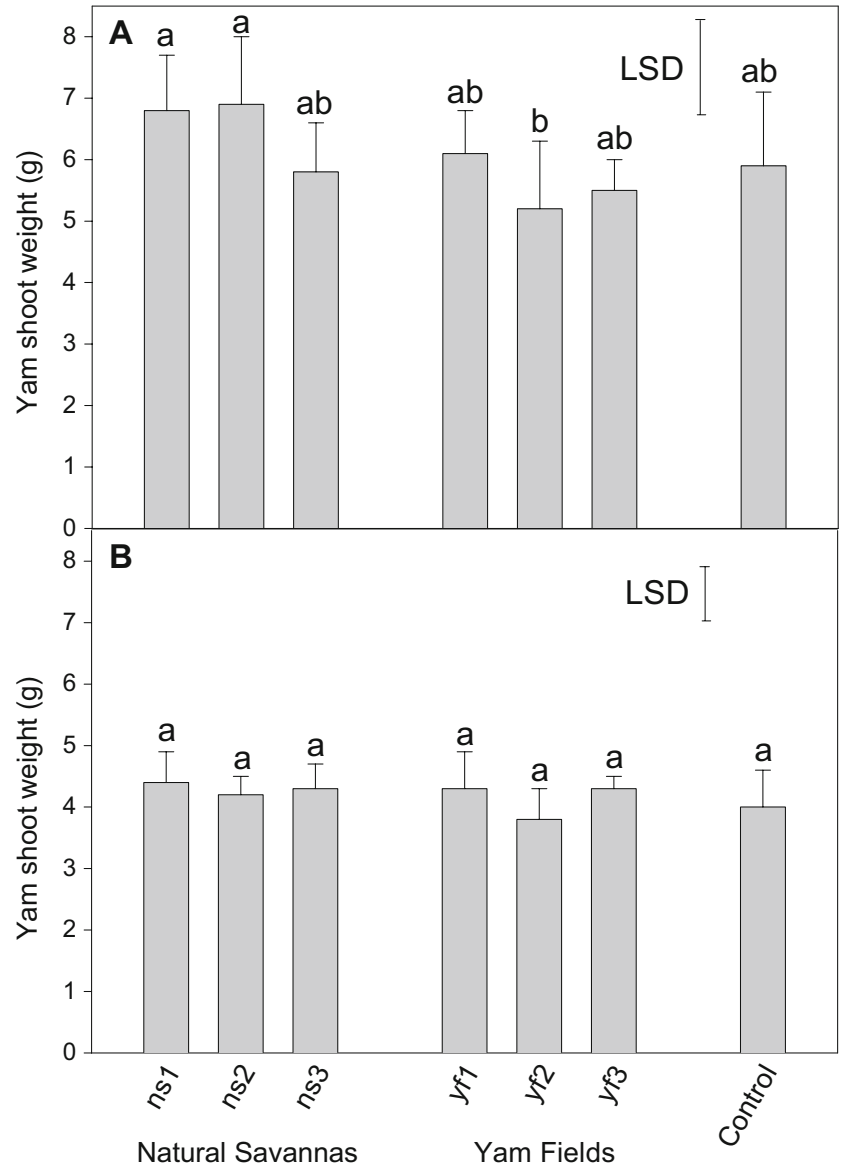

Fig. 7 Shoot dry weight of D. cayenensis (a) and D. rotundata (b) following 8 months cultivation in trap cultures using dry season field soils from three natural savannas (ns 1-3) and adjacent yam fields $(y f 1-3)$ as inocula and including a nonmycorrhizal control. Data are reported as averages and standard deviations for four replicate plots per field site. Columns with the same letter are not significantly different at $P=0.05$. LSD denotes the least significant difference between sites

system of sorghum. The current findings are indicative that yam is a highly mycotrophic plant and suggest significant AMF dependency. In this context, it is interesting to note that despite the much higher level of AMF root colonization of yam than of sorghum in the trap cultures, much less spores were produced with yam than with sorghum. Similar observations were also made at the ecosystem level in Central Europe (Oehl et al. 2003), where AMF communities present in seminatural grassland soil inocula colonized bait plant roots faster and more densely but with less abundant spore production than the soil inocula containing AMF communities from neighboring arable lands. Further investigations are needed to understand these mutual life history strategies.

AMF root colonization of yam in trap cultures was enhanced upon inoculated with soil from savannas as compared to inoculation with soil from adjacent yam fields.
This might be related to the observed reduction in AMF species richness in the course of the first year following clearance of the natural vegetation for yam cultivation (Tchabi et al. 2008). The current study reveals how the decline in AMF species richness following the land use change from natural savannas to yam cultivation results in reduced AMF infection potential, even in the traditional low-input farming system. This decline further illuminates the loss of biodiversity following land use change, even in the first year following clearance of the natural vegetation. It provides greater evidence concerning the loss of beneficial microorganisms (AMF richness) than was observed in the previous related study (Tchabi et al. 2008), where a dramatic decrease of AMF species richness was found with increasing land use intensity in the Sudan and Guinea savannas but not evidently during the transition to yam in the first year after slash-and-burn.

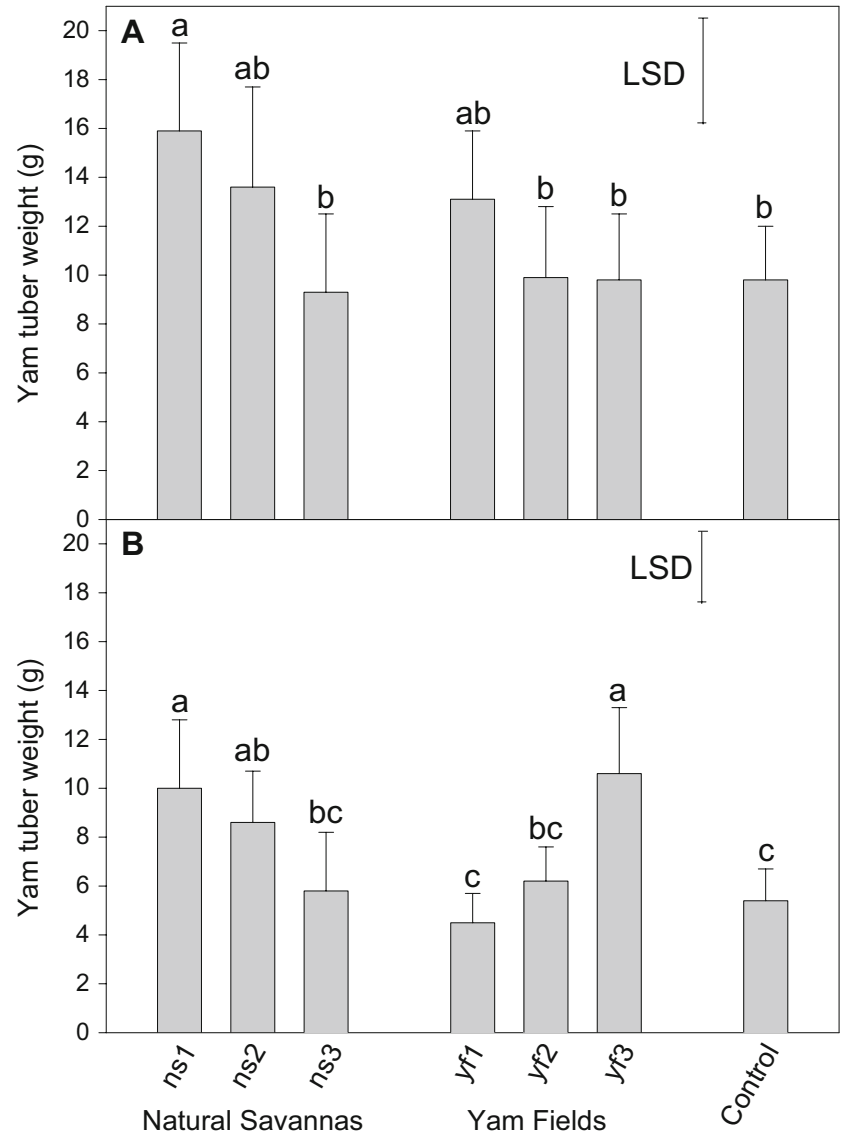

Fig. 8 Tuber dry weight of $D$. cayenensis (a) and D. rotundata (b) following 8 months cultivation in trap cultures using dry season field soils from three natural savannas (ns1-3) and adjacent yam fields $(y f 1-3)$ as inocula, and including a nonmycorrhizal control. Data are reported as averages and standard deviations for four replicate plots per field site. Nonsignificant differences between sites are shown by identical letters, determined using Fisher's Least Significant Difference $(L S D)$ at the $5 \%$ level following one-way ANOVA 
While yam shoot growth in the trap cultures was unaffected following inoculation with the soils from field sites, yam tuber development was substantially enhanced in some cases, compared with controls. Although other intrinsic factors related to in vitro plantlets could interfere with tuber development, the increased tuber production is more likely influenced by AMF given the outstanding high AMF root colonization. This further indicates that AMF may play an important role in yam nutrition and tuber production and explain the good production performance of yam immediately following savanna clearance, when AMF abundance is high as compared to subsequent years (Tchabi et al. 2008). Plant growth promotion by AMF is a wellestablished phenomenon across crops and climatic zones (e.g., Chaurasia and Hare 2005; Caglar and Akgun 2006; Smith and Read 2008). Further studies on yam growth promotion by AMF should now focus on the specificity and functionality of the symbiotic interaction and the influence of inocula levels on AMF-yam interactions under controlled and field conditions. A particular emphasis should focus on the selection of indigenous AMF isolates that hold promise for outstanding benefits for sustainable yam production.

\section{Conclusion}

By extensive spore morphotyping of field samples and, in addition, of samples obtained from prolonged trap cultures using different bait plant species, an outstanding AMF species richness was revealed in ecosystems of the SGS. To establish successful trap cultures for AMF present in such tropical ecosystems, use of soil inocula collected during the dry season should be considered essential, as the wet season inocula virtually failed. By using yam as bait plants in trap cultures followed by morphological identification of the newly formed AMF spores and by molecular assessment of the AMF community composition colonizing yam roots in the field, we could clearly show that yam engages in promiscuous symbiotic interactions with a wide range of AMF species. Spores of Gl. etunicatum and Ac. scrobiculata were most frequently detected in yam fields, and these AMF species also sporulated most rapidly and profusely in the trap cultures with yam. It will be challenging to investigate whether these, or other, more slowly sporulating species are more important, or alternatively, whether combinations of AMF species are better. Consequently, it will be useful to elucidate the role of AMF for the high yam productivity observed in the first year after savanna clearance and whether the later decline of yam productivity is directly associated with the decline of AMF species richness that is taking place in parallel.
Acknowledgement We thank Kurt Ineichen for his help and advice for maintaining the AMF. The work supported by grants from the Swiss Center for International Agriculture (ZIL: http://www.rfpp.ethz. ch), the Indo-Swiss Collaboration in Biotechnology (ISCB: http://iscb. epfl.ch/), and the Swiss National Science Foundation.

\section{References}

Adjakidje V (1984) Contribution à l'étude botanique des savanes guinéennes de la République Populaire du Bénin. Université de Bordeaux III, Bordeaux, - Thèse du troisième cycle

Adjanohoun EJ (1989) Contribution aux études ethnobotaniques et floristiques en République Populaire du Bénin. Agence de Coopération Culturelle et Technique, Paris

Ahn PM (1993) Tropical soils and fertiliser use. Longman Scientific \& Technical, Edinburgh

Ahulu ME, Nakata M, Nonaka M (2005) Arum- and Paris-type arbuscular mycorrhizas in a mixed pine forest on sand dune soil in Niigata Prefecture, Central Honshu, Japan. Mycorrhiza 15:129-136. doi:10.1007/s00572-004-0310-9

Altschul SF, Madden TL, Schaeffer AA (1997) Gapped BLAST and PSI-BLAST: a new generation of protein database search programs. Nucleic Acids Res 25:3389-3402. doi:10.1093/nar/ 25.17 .3389

Baimey H (2005) Scutellonema bradys as a pathogen of yam in Benin. PhD Thesis. University of Pretoria. Pretoria, South Africa, pp 146

Baimey H, Coyne D, Labuschagne N (2005) Assessment of inoculation methods in evaluating response of yam cultivars to infection by Scutellonema bradys. Nematology 7:375-379. doi:10. $1163 / 156854105774355518$

Baimey H, Coyne D, Labuschagne N (2006) Effect of fertilizer application on yam nematode (Scutellonema bradys) multiplication and consequent damage to yam (Dioscorea spp.) under field and storage conditions in Benin. Int J Pest Manage 52:63-70. doi:10.1080/09670870600552380

Bakhtiar Y, Miller D, Cavagnaro T, Smith S (2001) Interactions between two arbuscular mycorrhizal fungi and fungivorous nematodes and control of the nematode with fenamifos. Appl Soil Ecol 17:107-117. doi:10.1016/S0929-1393(01)00129-9

Bever JD, Morton JB, Antonovics J, Schultz PA (1996) Hostdependent sporulation and species diversity of arbuscular mycorrhizal fungi in a mown grassland. J Ecol 84:71-82. doi:10. 2307/2261701

Bever JD, Schultz PA, Pringle A, Morton JB (2001) Arbuscular mycorrhizal fungi: more diverse than meets the eye, and the ecological tale of why. Bioscience 51:923-931. doi:10.1641/ 0006-3568(2001)051<0923:AMFMDT>2.0.CO;2

Brundrett M, Melville L, Peterson L (1994) Practical Methods in Mycorrhizal Research. Mycologue Publications, University of Guelph, Guelph, Ontario, Canada

Caglar S, Akgun A (2006) Effects of vesicular-arbuscular mycorrhizal (VAM) fungi on the seedling growth of three Pistacia species. J Environ Biol 27:485-489

Carsky RJ, Wolo N, Manyong VM, Tian G (2001) Nutrient balance model for design of sustainable in yam cropping systems. In: Akoroda MO, Ngeve JM (eds) Tropical Root Crops. Proceedings of the 7th Triennal Symposium of the International Society for Tropical Root Crops-Africa Branch, Cotonou, Benin, pp 198209

Chaurasia B, Hare PK (2005) Hordeum vulgare: a suitable host for mass production of arbuscular mycorrhizal fungi from natural soil. Appl Ecol Environ Res 4:45-53 
Coursey DG (1984) Potential utilization of major root crops, with special emphasis on human, animal and industrial uses. In: Terry ER, Doku EV, Arene OB, Mahungu NM (eds) Tropical Root Crops: Production and Uses in Africa. Proceedings of the Second Triennial Symposium of the International Society for Root crops, Africa Branch, Duala, Cameroun, 14-19 August 1983, pp 25-35

Dalpé Y, Diop TA, Plenchette C, Gueye M (2000) Glomales species associated with surface and deep rhizosphere of Faidherbia albida in Senegal. Mycorrhiza 10:125-129. doi:10.1007/s0057 20000069

Dare M, Fagbola O, Asiedu R (2007) Heritability estimates of arbuscular mycorrhizal colonisation in Dioscorea species in yam growing regions of Nigeria. Proceedings of "Deutscher Tropentag" conference: Utilisation of diversity in land systems: Sustainable and organic approaches to meet human needs. Abstract for Poster section, Tropentag, October 9-11, 2007, Witzenhausen, Germany

Egesi CN, Odu BO, Ogunyemi S, Asiedu R, Hughes J (2007a) Evaluation of water yam (Dioscorea alata L.) germplasm for reaction to yam antracnose and virus disease and their effect on yield. J Phytopathol 155:536-543. doi:10.1111/j.1439-0434.2007. 01273.x

Egesi CN, Onyeka TJ, Asiedu R (2007b) Severity of anthracnose and virus desease on water yam (Dioscorea alata L.) in Nigeria I. Effects of yam genotype and date of planting. Crop Prot 26:1259-1265. doi:10.1016/j.cropro.2006.10.025

FAO (2007) Food and Agriculture Organization of the United Nation, Rome

FAOSTAT data (2007) Food and Agriculture Organization of the United Nation, Rome

Ferguson UT (1973) The effect of set characteristics and spacing on growth, development and yield of yams (Dioscorea spp). $\mathrm{PhD}$ thesis, University of the West Indies St. Augustine, Trinidad, West Indies, $219 \mathrm{pp}$

Gai JP, Christie P, Feng G, Lu XL (2006) Twenty years of research on community composition and species distribution of arbuscular mycorrhizal fungi in China: a review. Mycorrhiza 16:229-239. doi:10.1007/s00572-005-0023-8

Giovannetti M, Mosse B (1980) An evaluation of techniques for measuring vesicular arbuscular mycorrhizal infection in Roots. New Phytol 84:489-500. doi:10.1111/j.1469-8137.1980.tb04 556. $\mathrm{x}$

Husband R, Herre EA, Turner SL, Gallery R, Young JPW (2002) Molecular diversity of arbuscular mycorrhizal fungi and patterns of host association over time and space in tropical forest. Mol Ecol 11:2669-2678. doi:10.1046/j.1365-294X.2002.01647.x

IITA (2005) Annual Report of the International Institute of Tropical Agriculture. IITA-Ibadan, Nigeria

IITA (2006) Annual Report of the International Institute of Tropical Agriculture. IITA, Ibadan, Nigeria

Ile EI, Craufurd PQ, Battey NH, Asiedu R (2006) Phases of dormancy in yam tubers (Dioscorea rotundata). Ann Bot (Lond) 97:497504. doi:10.1093/aob/mcl002

Ile EI, Craufurd PQ, Asiedu R, Battey NH (2007) Duration from vine emergence to flowering suggests a long-day or rate of change of photoperoid response in white yam (Dioscorea rotundata Poir.). Environ Exp Bot 60:86-94. doi:10.1016/j.envexpbot.2006. 06.009

Kalu BA, Erhabor PO (1990) Production and econimic evaluation of white yam (Dioscorea rotundata) minisetts under ridge and bed production systems in a tropical Guinea savanna location, Nigeria. Trop Agric 69:78-82

Klironomos JN, Bednarczuk EM, Neville J (1999) Reproductive significance of feeding on saprophytic and arbuscular mycorrhizal fungi by the collembolan, Folsomia candida. Funct Ecol 13:756-761. doi:10.1046/j.1365-2435.1999.00379.x
Lekberg Y, Koide RT, Rohr JR, Aldrich-Wolfe L, Morton JB (2007) Role of niche restrictions and dispersal in the composition of arbuscular mycorrhizal fungal communities. J Ecol 95:95-105. doi:10.1111/j.1365-2745.2006.01193.x

Lovelock CE, Andersen K, Morton JB (2003) Arbuscular mycorrhizal communities in tropical forests are affected by host tree species and environment. Oecologia 135:268-279

Maduakor HO, Lal R, Opar-Nadi OA (1984) Effects of methods of seedbed preparation and mulching o the growth and yield of white yam (Dioscorea rotundata) on an Ultisol in south-east Nigeria. Field Crops Res 9:119-130. doi:10.1016/0378-4290(84) 90018-2

Mathimaran N, Ruh R, Jama B, Verchot L, Frossard E, Jansa J (2007) Impact of agricultural management on arbuscular mycorrhizal fungal communities in Kenyan Ferralsol. Agric Ecosyst Environ 119:22-32. doi:10.1016/j.agee.2006.06.004

$\mathrm{Ng}$ SYC (1988) In vitro tuberization in white yam (Dioscorea rotundata Poir). Plant Cell Tissue Organ Cult 14:121-128. doi:10. 1007/ BF00041185

Ng SYC (1992) Micropropagation of white yam (Dioscorea rotundata Poir). In: Bajaj YPS (ed) Biotechnology in Agriculture and Forestry, vol. 19. High Technology and Micropropagation 111. Springer-Verlag, Berlin, Germany, pp 135-159

$\mathrm{Ng}$ SYC (1994) Production and distribution of virus-free yam (Dioscorea rotundata Poir). In: Ofori IF, Hahn SK (eds) Proceedings of the 9th Symposium of the International Society of Tropical Root Crops, 20-26 October 1991. Accra, Ghana, pp 324-328

O'Sullivan JN, Jenner R (2006) Nutrient deficiencies in greater yam and their effects on leaf nutrient concentrations. J Plant Nutr 29:1663-1674. doi:10.1080/01904160600851569

O'Sullivan JN, Ernest J (2007) Nutrient deficiencies in lesser yam (Dioscorea esculenta) characterized using constant-water table sand culture. J Plant Nutr Soil Sci 170:273-282. doi:10.1002/ jpln.200625049

Odu BO, Asiedu R, Hughes JA, SA Shoyinka SA, Oladiran OA (2004) Identification of resistance to yam mosaic virus (YMV), genus Potyvirus in white Guinea yam (Dioscorea rotundata Poir.). Field Crops Res 89:97-105. doi:10.1016/j.fcr.2004. 01.009

Oehl F, Sieverding E, Ineichen K, Mäder P, Boller T, Wiemken A (2003) Impact of land use intensity on the species diversity of arbuscular mycorrhizal fungi in agroecosystem of Central Europe. Appl Environ Microbiol 69:2816-2824. doi:10.1128/ AEM.69.5.2816-2824.2003

Oehl F, Sieverding E, Mäder P, Dubois D, Ineichen K, Boller T, Wiemken A (2004) Impact of long-term conventional and organic farming on the diversity of arbuscular mycorrhizal fungi. Oecologia 138:574-583

Oehl F, Sieverding E, Ineichen K, Ris E-A, Boller T, Wiemken A (2005) Community structure of arbuscular mycorrhizal fungi at different soil depths in extensively and intensively managed agroecosystems. New Phytol 165:273-283. doi:10.1111/j.14698137.2004.01235.x

Oehl F, Sieverding E, Wiemken A (2007) History and biogeography of arbuscular mycorrhizal fungi-a global view. In: Maia LC, Malosso E, Yano-Melo AM (eds) Micologia-avanços no conhecimento. $5^{\circ}$ Congresso Brasileiro de Micologia, 11-16 November 2007. Recife, Brazil, pp 256-258

Oehl F, de Souza FA, Sieverding E (2008) Revision of Scutellospora and description of five new genera and three new families in the arbuscular mycorrhiza-forming Glomeromycetes. Mycotaxon 106:311-360

Olasantan FO (1999) Effect of time of mulching on soil temperature and moisture regime and emergence, growth and yield of white yam in western Nigeria. Soil Tillage Res 50:215-221. doi:10. 1016/S0167-1987(98)00192-5 
Onwueme IC, Haverkort JA (1991) Modelling growth and productivity of yams (Dioscorea spp.): Prospects and problems. Agric Syst 36:351-367. doi:10.1016/0308-521X(91)90015-3

Öpik M, Moora M, Liira J, Zobel M (2006) Composition of rootcolonizing mycorrhizal fungal communities in different ecosystems around the globe. J Ecol 94:778-790. doi:10.1111/j.13652745.2006.01136.x

Orkwor GC (1998) The importance of yam. In: Orkwor GC, Asiedu R, Ekanayake IJ (eds) Food Yams: Advances in Research. IITA and NRCRI, Nigeria, pp 1-12

Oyetunji OJ, Afolayan ET (2007) The relationships between relative water content, chlorophyll synthesis and yield performance of yam (Dioscorea rotundata) as affected by soil amendments and mycorrhizal inoculation. Arch Agron Soil Sci 53:335-344. doi:10.1080/03650340601149310

Ravi V, Aked J, Balagopalan C (1996) Review on tropical root and tuber crops. I. Storage methods and quality changes. Crit Rev Food Sci Nutr 36:661-709

Redecker D (2000) Specific PCR primers to identify arbuscular mycorrhizal fungi within colonized roots. Mycorrhiza 10:73-80. doi:10.1007/s005720000061

Salako FK, Olowokere FA, Tian G, Kirchhof G, Osiname O (2007) Ground cover by three crops cultivated on marginal lands in southwestern Nigeria and implications fror soil erosion. Span J Agric Res 5:497-505

Sanginga N, Carsky RJ, Darshiell K (1999) Arbuscular mycorrhizal fungi respond to rhizobial inoculation and cropping systems in farmers' fields in the Guinea savanna. Biol Fertil Soils 30:179186. doi: $10.1007 / \mathrm{s} 003740050606$

SAS Institute, Inc (2007) SAS User's Guide: Statistics. SAS, Cary

Schenck NC, Pérez Y (1990) A manual for identification of vesiculararbuscular mycorrhizal fungi. INAM University of Florida, Gainesville

Smith SE, Read DJ (2008) Mycorrhizal Symbiosis, 3rd edn. Academic Press, San Diego

Sotomayor-Ramirez D, Gonzalez-Velez A, Roman-Paoli E (2003) Yam (Dioscorea spp.) response to fertilization in soils of the semiarid sothern coast of Puerto Rico. J Agric Univ P R 87:91-103
Suja G, Nair VM, Sarawathy P, Pushpakumari R (2003) Plant population and sett size efects on white yam (Dioscorea rotundata Poir.) intercropped in coconut gardens. Trop Agric 80: $157-162$

Swofford DL (2001) PAUP*. Phylogenetic Analysis Using Parsimony (*and Other Methods). Sinauer, Sunderland

Sýkorová Z, Wiemken A, Redecker D (2007) Co-occurring Gentiana verna and Gentiana acaulis and their neighboring plants in two Swiss upper montane meadows harbor distinct arbuscular mycorrhizal fungal communities. Appl Environ Microbiol 73: 5426-5434. doi:10.1128/AEM.00987-07

Tchabi A 2008. Arbuscular mycorrhizal fungi in the sub-Saharan savanns of Benin and their association with yam (Dioscorea spp.): Potential of yam growth promotion and reduction of nematode infestation. PhD thesis, University of Basel, Switzerland

Tchabi A, Coyne D, Hountondji F, Lawouin L, Wiemken A, Oehl F (2008) Arbuscular mycorrhizal fungal communities in subSaharan savannas of Benin, West Africa, as affected by agricultural land use intensity and ecological zone. Mycorrhiza 18:181-195. doi:10.1007/s00572-008-0171-8

Tiunov AV, Scheu S (2005) Arbuscular mycorrhiza and Collembola interact in affecting community composition of saprotrophic microfungi. Oecologia 142:636-642. doi:10.1007/s00442-0041758-1

Uchendu EE (2000) Effect of arbuscular-mycorrhizal fungi inoculation on establishment of in-vitro Dioscorea rotundata plantlets in soil. B.Sc Thesis, University of Ibadan, Nigeria, 58p

Valenzuela HR, DeFrank J (1995) Agroecology of tropical underground crops for small-scale agriculture. Crit Rev Plant Sci 14:213-238. doi:10.1080/713608116

Vandenkoornhuyse P, Husband R, Daniell TJ, Watson J, Duck JM, Fitter AH, Young JPW (2002) Arbuscular mycorrhizal community composition associated with two plant species in a grassland ecosystem. Mol Ecol 11:1555-1564. doi:10.1046/j.1365-294X. 2002.01538.x

Vander Zaag P, Fox RL (1980) The phosphorus requirements of yams (Dioscorea spp.). Trop Agric 57:97-106 